Article

\title{
Energy Evaluation of a PV-Based Test Facility for Assessing Future Self-Sufficient Buildings
}

\author{
Angela Amato (D), Matteo Bilardo (D), Enrico Fabrizio (D), Valentina Serra * and Filippo Spertino (D) \\ Department of Energy, Politecnico di Torino, Corso Duca degli Abruzzi 24, 10129 Torino, Italy; \\ angela.amato@polito.it (A.A.); matteo.bilardo@polito.it (M.B.); enrico.fabrizio@polito.it (E.F.); \\ filippo.spertino@polito.it (F.S.) \\ * Correspondence: valentina.serra@polito.it; Tel.: +39-011-0904-431
}

Citation: Amato, A.; Bilardo, M.; Fabrizio, E.; Serra, V.; Spertino, F. Energy Evaluation of a PV-Based Test Facility for Assessing Future Self-Sufficient Buildings. Energies 2021, 14, 329. https://doi.org/ 10.3390/en14020329

Received: 19 November 2020

Accepted: 4 January 2021

Published: 8 January 2021

Publisher's Note: MDPI stays neutral with regard to jurisdictional clai$\mathrm{ms}$ in published maps and institutional affiliations.

Copyright: $\odot 2021$ by the authors. Licensee MDPI, Basel, Switzerland. This article is an open access article distributed under the terms and conditions of the Creative Commons Attribution (CC BY) license (https:// creativecommons.org/licenses/by/ $4.0 /)$.
Abstract: In recent years, investigations on advanced technological solutions aiming to achieve high-energy performance in buildings have been carried out by research centers and universities, in accordance with the reduction in buildings' energy consumption required by European Union. However, even if the research and design of new technological solutions makes it possible to achieve the regulatory objectives, a building's performance during operation deviates from simulations. To deepen this topic, interesting studies have focused on testing these solutions on full-scale facilities used for real-life activities. In this context, a test facility will be built in the university campus of Politecnico di Torino (Italy). The facility has been designed to be an all-electric nearly Zero Energy Building (nZEB), where heating and cooling demand will be fulfilled by an air-source heat pump and photovoltaic generators will meet the energy demand. In this paper, the facility energy performance is evaluated through a dynamic simulation model. To improve energy self-sufficiency, the integration of lithium-ion batteries in a HVAC system is investigated and their storage size is optimized. Moreover, the facility has been divided into three units equipped with independent electric systems with the aim of estimating the benefits of local energy sharing. The simulation results clarify that the facility meets the expected energy performance, and that it is consistent with a typical European nZEB. The results also demonstrate that the local use of photovoltaic energy can be enhanced thanks to batteries and local energy sharing, achieving a greater independence from the external electrical grid. Furthermore, the analysis of the impact of the local energy sharing makes the case study of particular interest, as it represents a simplified approach to the energy community concept. Thus, the results clarify the academic potential for this facility, in terms of both research and didactic purposes.

Keywords: building energy performance; building renewables integration; PV-based; test facility; battery energy storage potential; local energy sharing potential; self-sufficiency; self-consumption

\section{Introduction}

Over the years, several directives have been issued at the European level regarding the energy performance of buildings. European Directive 2010/31/EU, known as the Energy Performance of Buildings Directive (EPBD), defines nearly Zero Energy Buildings (nZEBs) as buildings characterized by low energy consumption. Their energy demand is fulfilled to a significant extent by renewable energy, a share of which is produced onsite or nearby. Member States of European Union must ensure that all new buildings are nZEBs by 31 December 2020 and that public buildings are after 31 December 2018. Moreover, the transformation of buildings undergoing major renovations into nZEBs must be encouraged [1]. Directive 2018/844/EU, the latest review of the EPBD, makes an essential amendment to Directive 2010/31/EU regarding existing buildings. Through a long-term renovation strategy, each Member State must support the energy performance upgrade of all buildings to nZEBs, including the existing ones [2]. These strategies will aim to achieve highly energy-efficient and decarbonized national building stocks by 2050 . 
From the overview just described, all new European buildings should be identified as nZEBs. However, although the regulatory context defines the features of an nZEB, the energy performance of new buildings does not always confirm the features of nZEBs. This gap between design and operation is an increasingly frequent and widely discussed problem [3]. Although the concept of nZEBs is widespread and approved, it is always difficult to give a unanimous definition. The definition of nZEBs should in fact pass through an accurate analysis of performance not only in the design phase, but also during the operational phase. One of the main problems in the consistency of these two phases is load matching, or the ability that the building has over time to meet its energy needs. A building that was not designed as an nZEB, when able to match its load using careful resource monitoring and management, could in many cases perform similar to or better than an nZEB [4]. On the contrary, a high-performance building that undergoes a major mismatch between generation and use of energy often results in a worse operational performance. The nZEB problem certainly calls into question an integration between different systems, including the envelope, Heating Ventilation and Air Conditioning (HVAC) equipment, occupant behavior, etc., which can hardly be foreseen and controlled through a traditional design [5]. In this context, studying in some detail the interactions between the building envelope and the HVAC system is essential to achieve the nZEB target. For this reason, test facilities are helping to define and deepen the nZEB life cycle, allowing the study of integrated design, followed by continuous and detailed monitoring. In fact, several studies have been conducted by research centers and universities to explore and test advanced technological solutions in ad-hoc facilities [6]. Academic research and testing are essential to assess and promote the best construction techniques and the best solutions for energy systems to optimize the design process of buildings [7], achieving low energy consumption and environmental impact while meeting users' needs [8].

\subsection{Test Facilities for Building Performance Research}

In recent years, many research centers and universities have focused their research on nZEBs through the construction of full-scale test facilities, to study the effect of design variables on the performance of buildings or technology solutions in reliable and realistic conditions [9]. Numerous articles that report the results of experimental campaigns conducted on these facilities have supported this research approach [10]. Among the studies that have focused on testing high-performance facilities, the most interesting are certainly those that are used for real-life activities, such as offices or residential use. This type of test facility makes the research study even more plausible, as they combine real use with advanced monitoring and control. For the purpose of the work of this paper, seven test facilities were considered limiting the analysis to the European context, which constitutes the legislative, technical and economical frameworks in which the project of this facility was conceived. Table 1 summarizes the description and the experimental investigations carried out on the seven above-mentioned European facilities for building performance research.

Table 1. Examples of European test facilities for building performance research.

\begin{tabular}{clll}
\hline Test Facility & Location & \multicolumn{1}{c}{ Brief Description } & Main Objective of Exp. Tests \\
\hline nZEB & Tallinn (EE) & $\begin{array}{l}\text { Multiple room building with a } \\
\text { heated area of } 100 \mathrm{~m}^{2} .\end{array}$ & Heating system performance. \\
\hline Passive House & Gent (BE) & $\begin{array}{l}\text { Building consisting of two lecture } \\
\text { rooms, a staircase and a technical } \\
\text { room. Each lecture room has a } \\
\text { volume of } 380 \mathrm{~m}^{3} .\end{array}$ & Ventilation strategies. \\
\hline Office mock-up & Northern Italy & $\begin{array}{l}\text { Office room with a floor area of } \\
\text { around } 19 \mathrm{~m}^{2} \text { and } 3.45 \mathrm{~m} \text { high. }\end{array}$ & $\begin{array}{l}\text { Advanced integrated } \\
\text { façade performance. }\end{array}$ \\
\hline
\end{tabular}


Table 1. Cont.

\begin{tabular}{ccll}
\hline Test Facility & Location & \multicolumn{1}{c}{ Brief Description } & Main Objective of Exp. Tests \\
\hline The Cube & Aalborg (DK) & $\begin{array}{l}\text { Office room with a floor area of } \\
\text { around } 10 \mathrm{~m}^{2} \text { and } 2.75 \mathrm{~m} \text { high. }\end{array}$ & $\begin{array}{l}\text { Validation of dynamic } \\
\text { fenestration models; cooling } \\
\text { systems performance. }\end{array}$ \\
\hline Efficiency Plus House & Berlin (DE) & $\begin{array}{l}\text { Two-floor house with a living area of } \\
\text { around } 130 \mathrm{~m}^{2} .\end{array}$ & Energy performance. \\
\hline Salford Energy House & Salford (UK) & $\begin{array}{l}\text { Replica of a Victorian house within } \\
\text { an environmental chamber. }\end{array}$ & Retrofit options potential. \\
\hline Brescia Smart Campus & Brescia (IT) & University classroom building. & $\begin{array}{l}\text { Solar energy impact and } \\
\text { internal comfort. }\end{array}$ \\
\hline
\end{tabular}

In detail, an nZEB facility was built at the Tallinn University of Technology (Estonia) in order to perform experimental tests on the heating system. It is a multiple room facility with timber frame walls and concrete floor characterized by a heated area of $100 \mathrm{~m}^{2}$ [13]. A comparison between different heating terminals coupled with varying schemes of control was carried out. In [11], the objective was to assess and quantify the control accuracy and thermal comfort parameters of all the analyzed configurations. At the same time, in [12] the experimental results were used to calibrate terminals and controller models in a simulation software. In [13], the effect of hydronic balancing on the performance of an underfloor heating system with an air-to-water heat pump was studied.

A test facility located in the Technology campus Gent of Leuven University (Belgium) is presented in [14]. The facility, certified according to Passive House standard, consists of two lecture rooms, a staircase and a technical room built on top of an existing building. The lecture rooms are two identical cuboids with a volume of $380 \mathrm{~m}^{3}$ each but different thermal mass. The facility is equipped with high-performing Air Handling Unit (AHU) and lighting system, a wood pellet boiler and motor-controlled sun-shading windows managed by a monitoring and control system. It is suitable for testing ventilation strategies thanks to its envelope and plant features.

In [15], a mock-up of an office building in Northern Italy was used for testing and comparing the energy performance and the thermophysical behavior of two configurations of the same responsive façade technology. The facility has a floor area of around $19 \mathrm{~m}^{2}$, and it is equipped with a combined air system and radiant panel for fulfilling the heating and cooling energy demand.

The impact of dynamic fenestration on energy performance has also been investigated thanks to "The Cube", a test facility that models a $10 \mathrm{~m}^{2}$ wooden office room at Aalborg University (Denmark). In [16], experimental measurements conducted on "The Cube" were used to validate a simplified calculation method for evaluating the thermal needs of a building with smart glazed façade controlling insulated shutter, venetian blind, natural ventilation and night cooling. Moreover, experimental data related to this test facility were adopted for the validation of double skin façade models in [17]. "The Cube" was also useful for the comparison of active chilled beam and radiant wall cooling systems. In [18], the study of convective heat transfer of the two systems was carried out and in [19] their energy performance and the comfort level in the test room were evaluated.

A wooden test facility, known as "Efficiency House Plus", was built near the Technical University of Berlin (Germany) as a showroom for the public. The facility was built in accordance with the winning project of the competition announced by the German Federal Ministry of Transport, Building and Urban Development in 2010 [21]. The "Efficiency House Plus" is an all-electric two-floor residential facility with a living area of around $130 \mathrm{~m}^{2}$. It satisfies its energy demand for HVAC, Domestic Hot Water (DHW), household appliances and electric vehicles charging thanks to a PhotoVoltaic (PV) system coupled to a battery. The facility was inhabited for about a year by a family of four to test its daily 
use suitability. During this period, energy consumption and production were monitored in order to evaluate the energy performance of the building [20].

A different approach has been adopted by Salford University (UK). A replica of a Victorian house was built to analyze the energy-saving potential of various retrofit options. It is a two-floor house consisting of two bedrooms, a dining kitchen, a living room and a bathroom. The facility, named "Salford Energy House", is representative of about $30 \%$ of the UK's existing houses. It has solid brick walls, suspended timber floors, lath and plaster ceilings, single-glazed windows and uninsulated base state. It is equipped with a wet central heating system fired by a gas boiler [22]. Most retrofit studies were carried out through a numerical model, but the test facility was essential for the accuracy of the model. Indeed, the facility is a house of typical construction which is continuously monitored while being disconnected from the unpredictability of weather conditions and human behavior since it is located in an environmental chamber and is not occupied [22]. In [22], energy savings due to the installation of room thermostats and thermostatic radiator valves were demonstrated, and in [23] the impact of window coverings was evaluated. Ref. [24] focused on improving building fabric thermal performance, while in [25] the risk of summer overheating due to a deep retrofit was analyzed.

Finally, a study conducted by De Angelis et al. [26] at the University Campus of Brescia (Italy), demonstrated the importance of Building Information Modelling (BIM) and Building Energy Model (BEM) tools for the energy renovation of a university classroom, with the aim of pursuing the balance between generated and consumed energy. A monitoring system was developed in the same classroom to refine the energy model and plan improvement interventions with the goal of reaching the nZEB target.

A new test facility will soon be added to the current ones, some significant examples of which have been described above. Indeed, an nZEB test facility, available to students and staff, will be built in the university campus of the Politecnico di Torino. It has been optimized from an architectural and construction point of view (layout, materials selected for the envelope, windows) and it is equipped with energy systems integrated into the building (PV systems, energy storage systems, heat pump).

Users will be scheduled and monitored (presence and activity will be registered) and, in order to avoid uncertainties related to the occupants' behavior, no interaction with envelope and HVAC systems will be allowed. Internal conditions will be defined so as to provide a comfortable environment (thermal, acoustic and lighting conditions will be maintained to ensure high Indoor Environmental Quality (IEQ), but periodic surveys will be carried out).

The main challenge of this facility is the possibility of studying the nexus between energy demand and energy supply which allows exploring issues of paramount importance in nZEB, related to the effectiveness of control and management strategies of the systems. When the building is equipped with PV panels and the use of electric storage, the effects of the time span between the peaks of electrical production and thermal power demand can be mitigated, as in this case, and interesting insight can be provided. Investigations may include, for example, different matching time periods (from daily to seasonal scale), storage types and medium, testing advanced controller models.

This new facility is expected to contribute to the most lacking category of studies available in the literature. In the current preconstruction phase of the test facility, it is possible to evaluate how the designed building and its integrated energy systems behave in realistic conditions through simulations and the analysis of parameters suitable for assessing its energy (thermal and electrical) performance. After construction, it will be possible to proceed with monitoring the facility in operation in order to validate models and explore simulation-based optimization.

\subsection{Aim and Organization of the Work}

In this work, the energy assessment results of an all-electric test facility that will be built in the university campus of Politecnico di Torino (Italy) are presented. Based on 
the construction project, the energy model of the facility, including HVAC equipment, PV systems and Battery Energy Storage Systems (BESSs), was developed. The thermal performance analysis demonstrates that the facility is in line with the average European nZEB target, evidencing the high-energy performance of the building. To evaluate the overall electrical performance, self-sufficiency (SS) and self-consumption (SC) were identified as suitable Key Performance Indicators (KPIs). The facility was divided into three units equipped with independent electric systems in order to enable the investigation of the local energy sharing. Indeed, two simulation scenarios were analyzed with the aim of demonstrating that BESS installation can increase the use of local renewable energy, enhancing SS and SC. In the first scenario, the three units can exchange electrical power only with the external grid if there is a local energy generation surplus or deficit with respect to the demand. In the second one, the units can also exchange the self-produced energy among them. In both scenarios, the possibility of installing Li-ion batteries was investigated. Several BESS capacities were analyzed in order to evaluate their different impacts on the KPIs. This allowed a proper battery sizing from an energy point of view.

The results of this study, together with those of other analysis conducted prior to construction, can be validated when the facility is operational. However, the results presented in this paper were taken into consideration for the design choices when defining the building requirements. In addition, the test facility could be useful for further experimental investigations for research and didactic purposes in different scientific sectors (thermophysical, electrical and electronic).

The paper is organized as follows: Section 2 introduces the materials and methods adopted, describing the test facility under study and its energy model. Moreover, it defines the thermal and electrical energy performance indicators used and the two simulation scenarios analyzed. The results of the study are reported in Section 3 and discussed in Section 4 .

\section{Materials and Methods}

\subsection{Case Study}

The test facility analyzed in this work was conceived within the PhotoVoltaic Zero Energy Network (PVZEN) research project of Politecnico di Torino, involving the Department of Energy (DENERG), the Department of Architecture and Design (DAD) and the Department of Electronics and Telecommunications (DET). The goal of the project is to build an all-electric nZEB that fulfils its energy demand through PV systems and uses BESSs to be independent from the external electrical grid [27].

The architectural project of the facility was developed within the first edition of the 2nd Level Master "Architettura delle Costruzioni in legno" (Architecture of wooden buildings), offered by Politecnico di Torino. The facility will be built in the campus of Politecnico. It consists of four rooms, separated by partition walls: a control room, two study rooms and a technical room. It is a prefabricated building with a rectangular layout. The area occupied by the facility is $196.3 \mathrm{~m}^{2}(11.25 \times 17.45 \mathrm{~m})$, including an outdoor zone with wheelchair ramp and steps and a shed-covered zone at the glazed entrance doors of the study rooms and the control room. Thus, the interior air-conditioned area is around $96.8 \mathrm{~m}^{2}$. The ceiling height varies between 2.8 and $3.7 \mathrm{~m}$ above the floor level since the roof is tilted $\left(13.4^{\circ} \mathrm{on}\right.$ SE side, $15^{\circ}$ on NW side).

In Figure 1, the facility layout is presented, highlighting the distribution of the rooms and the orientation of the building. 


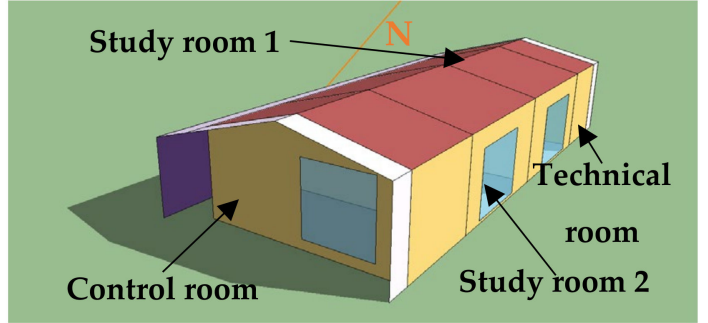

(a)

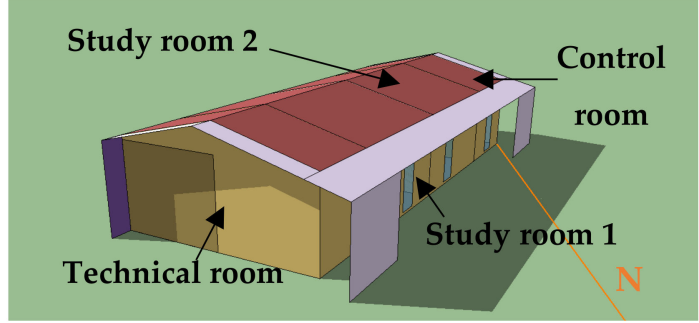

(b)

Figure 1. Facility layout seen from the South (a) and North (b).

The equipment and the size of the rooms are different as they have been designed for carrying out different kind of activities. The useful area and the function of each room are described in Table 2.

Table 2. Description of the test facility rooms.

\begin{tabular}{ccl}
\hline Room & Useful Area & \multicolumn{1}{c}{ Function } \\
\hline Technical room & $15.7 \mathrm{~m}^{2}$ & Location of electronic and HVAC equipment. \\
Study room 1 & $30.4 \mathrm{~m}^{2}$ & Hosting students. \\
Study room 2 & $30.4 \mathrm{~m}^{2}$ & Hosting students. \\
Control room & $20.3 \mathrm{~m}^{2}$ & Monitoring of energy systems and performance. \\
\hline
\end{tabular}

\subsection{Energy Modelling}

\subsubsection{Building Model}

The 3D model of the facility was drawn using the OpenStudio plug-in [28] for the design software SketchUp [29] and following the architectural project described in the previous subsection. Then, the SketchUp output file was converted into an Input Data File (IDF) file, editable by the building energy simulation program EnergyPlus [30]. Using EnergyPlus, the building model was completed with the definition of its envelope and all the assumptions relevant for assessing the future energy performance of the facility in operation. In addition to the building features, a weather data file referred to Torino was required for the energy simulation. The selected dataset was an International Weather for Energy Calculations (IWEC) file, which is a result of the ASHRAE Research Project 1015 [31].

The facility, built using eco-sustainable and innovative materials, is characterized by the construction features listed in Table 3.

Table 3. Main features of the facility envelope.

\begin{tabular}{cc}
\hline Feature & Value \\
\hline Conditioned floor area & $96.8 \mathrm{~m}^{2}$ \\
Conditioned volume & $501 \mathrm{~m}^{3}$ \\
Envelope surface/conditioned volume ratio & $0.85 \mathrm{~m}^{-1}$ \\
Transparent/opaque envelope surface ratio & $6.6 \%$ \\
Opaque envelope surface & $400 \mathrm{~m}^{2}$ \\
$\bar{U}_{\mathrm{op}}$ & $0.16 \mathrm{~W} / \mathrm{m}^{2} \mathrm{~K}$ \\
$\bar{U}_{\mathrm{tr}}$ & $0.55 \mathrm{~W} / \mathrm{m}^{2} \mathrm{~K}$ \\
\hline
\end{tabular}

In order to perform the energy simulation, internal thermal and electrical loads, representing the real future use of the facility by students and staff, were defined. The facility was assumed to be opened from 8:30 up to 19:00 on working days. Its closure was scheduled on weekends, for religious holidays and for summer holidays (August). During opening hours, the control room was assumed to be constantly occupied by 3 people, while the study rooms had variable occupations (from 3 up to 10 students). No regular 
occupation was expected for the technical room. The air ventilation rate for the control room and the study rooms was based on the occupancy (10 L/s per person) [32], while for the technical room it was assumed equal to $0.3 \mathrm{vol} / \mathrm{h}$ during opening hours. The air infiltration rate was set to $0.15 \mathrm{vol} / \mathrm{h}$, a typical value for office buildings. Table 4 reports the temperature set points for heating and cooling seasons.

Table 4. Temperature set points [33].

\begin{tabular}{cccc}
\hline \multicolumn{2}{c}{ Heating Season } & \multicolumn{2}{c}{ Cooling Season $^{1}$} \\
\hline Opening Hours & Closing Hours & Opening Hours & Closing Hours \\
\hline $20{ }^{\circ} \mathrm{C}^{2}$ & $13^{\circ} \mathrm{C}$ & $26{ }^{\circ} \mathrm{C}$ & $30^{\circ} \mathrm{C}$ \\
\hline
\end{tabular}

1 The cooling system was also turned on in August in order to avoid any overheating $\left(\mathrm{T}>35^{\circ} \mathrm{C}\right)$ and prevent equipment damage. ${ }^{2}$ For the technical room, $15^{\circ} \mathrm{C}$ was chosen because there is no regular occupation.

The total electrical load of the facility includes the energy used by workstations, projectors, ceiling lights and ventilation system (see Table 5), summed up to heat pump consumption, the model of which will be discussed in the next subsection.

Table 5. Description of the facility equipment.

\begin{tabular}{cll}
\hline Equipment & \multicolumn{1}{c}{ Description } & \multicolumn{1}{c}{ Energy Consumption } \\
\hline Workstations & $\begin{array}{l}\text { 23 workstations (3 in the control } \\
\text { room and 10 in each study room) } \\
\text { equipped with a laptop and a LED } \\
\text { lamp. Their operational schedule } \\
\text { follows the occupancy. }\end{array}$ & $\begin{array}{l}\text { A LED lamp absorbs 9 W; a } \\
\text { laptop consumes } \approx 50 \mathrm{~W} \\
\text { for few minutes at start, then } \\
\text { absorbs } \approx 35 \mathrm{~W} .\end{array}$ \\
\hline Projectors & $\begin{array}{l}\text { 1 projector in each study room that } \\
\text { works for 4 h a day. }\end{array}$ & A projector absorbs 190 W. \\
Ceiling lights & $\begin{array}{l}\text { They are turned on for the entire } \\
\text { opening time. }\end{array}$ & A ceiling light consumes 26 W. \\
\hline Ventilation system & $\begin{array}{l}\text { It is turned on for the entire } \\
\text { opening time. }\end{array}$ & $\begin{array}{l}\text { Requires 0.50 Wh for each cubic } \\
\text { meter of air entering the } \\
\text { facility [34]. }\end{array}$ \\
\hline
\end{tabular}

The four rooms of the facility were divided into three units equipped with independent electric systems in order to estimate the benefits provided by the local energy sharing, defined in Section 2.4 as the second simulation scenario. Unit 1 consists of the control room and the technical room, unit 2 is study room 1 and unit 3 is study room 2 .

\subsubsection{Heat Pump Model}

A reversible Air-Source Heat Pump (ASHP) was considered as the primary system to meet the winter/summer heating/cooling loads of the entire building. The ASHP model was generated after the building energy model, using the building thermal load as the heat pump forcing function. Based on the design heating/cooling loads, a reversible heat pump with a peak power equal to $9.2 \mathrm{~kW}$ in winter conditions and $9.5 \mathrm{~kW}$ in summer conditions was sized. After choosing the most suitable ASHP for the building, the heat pump performance map was developed, starting from the data provided by the manufacturer. As operating conditions, a winter operation with a temperature drop $(\Delta T)$ of $45 / 40{ }^{\circ} \mathrm{C}$ to the condenser and a summer operation with a temperature rise of $12 / 7^{\circ} \mathrm{C}$ to the evaporator were assumed. Operating conditions were defined taking into account the designed HVAC systems, which include a radiant floor and a centralized air handling unit. Table 6 summarizes the rated condition of the ASHP, as declared by the manufacturer, while Figure 2 represents the performance curves in winter (a) and summer (b) conditions. 
Table 6. Air-source heat pump rated performance.

\begin{tabular}{ccc}
\hline Feature & Cooling Condition & Heating Condition \\
\hline Thermal power & $9.5 \mathrm{~kW}$ & $9.2 \mathrm{~kW}$ \\
Electrical power & $3.1 \mathrm{~kW}$ & $3.0 \mathrm{~kW}$ \\
$\Delta T$ & $12 / 7^{\circ} \mathrm{C}$ & $45 / 40^{\circ} \mathrm{C}$ \\
EER/COP & 3.01 & 3.07 \\
Water flow & $1613 \mathrm{~L} / \mathrm{h}$ & $1619 \mathrm{~L} / \mathrm{h}$ \\
\hline
\end{tabular}

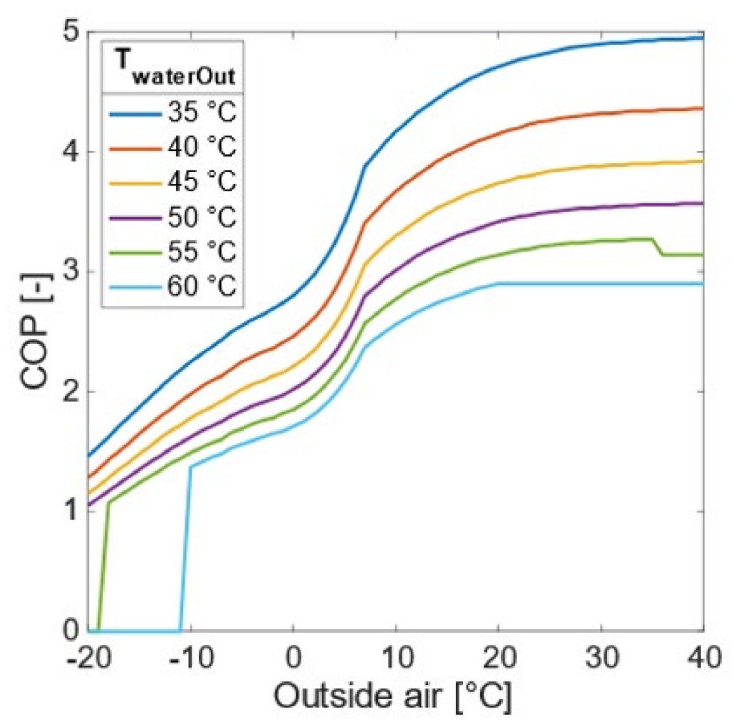

(a)

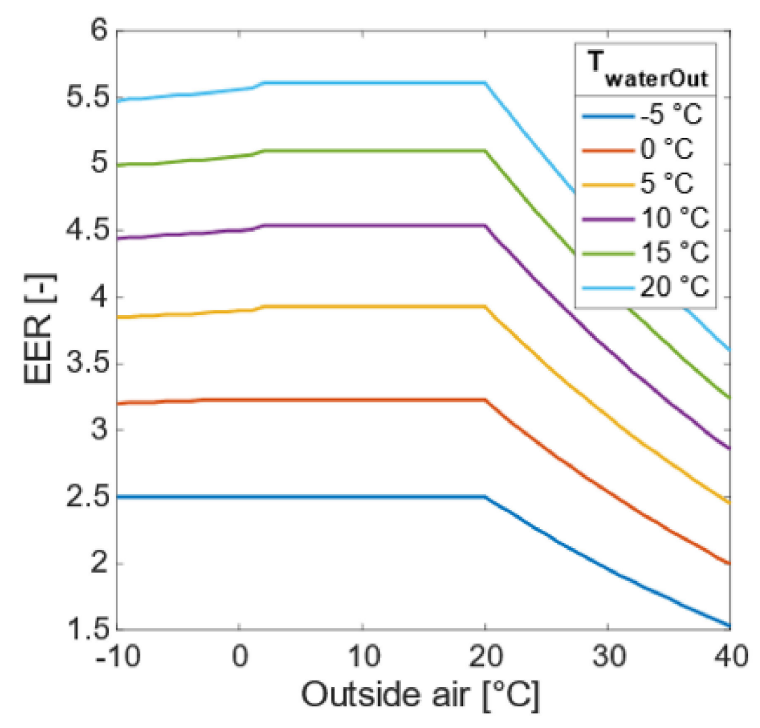

(b)

Figure 2. Air-Source Heat Pump (ASHP) performance map in heating (a) and cooling (b) conditions.

With the aim of designing a fully electric building, the quarter-hour electrical demand required by the ASHP was calculated starting from the building thermal demand, previously assessed using the thermoenergy model described in the previous subsection. The performance of the ASHP, in terms of Coefficient of Performance (COP) and Energy Efficiency Ratio (EER), was assessed using the performance map, considering the hourly climatic conditions of the building model (IWEC weather data for Torino). The calculation model for assessing the dynamic electrical consumption of the heat pump was developed in the MATLAB ${ }^{\circledR}$ environment [35]. This process consists of the elaboration of the quarterhour energy demand produced by the thermoenergy model of the building developed in EnergyPlus. The building thermal load becomes the input of the heat pump model: in each time interval, the thermal demand is divided by the performance coefficient of the ASHP, evaluated considering the IWEC weather conditions and the fixed $\Delta T$ on the evaporator/condenser. The ASHP model evaluates the electrical energy need of the building for heating and cooling purposes.

\subsubsection{PV System}

As discussed in Section 2.2.1, the test facility will be used by students and staff in the central hours of the day, akin to a typical tertiary sector building. Thus, a good matching between energy consumption and PV generation power profiles is expected [36]. For this reason, PV generators will be installed to supply the energy demand.

Monocrystalline silicon PV modules will be mounted. The selected modules have a rated power of $360 \mathrm{~W}$ and an efficiency of $22.2 \%$, provided by the manufacturer under standard test conditions (solar irradiance $G_{\text {STC }}=1000 \mathrm{~W} / \mathrm{m}^{2}$, cell temperature $T_{\text {STC }}=25^{\circ} \mathrm{C}$, air mass $A M=1.5$ ). PV power profiles were generated by providing EnergyPlus with manufacturer's data in order to build the Single-Diode Model (SDM) of the selected solar 
module and evaluate the power production [37]. According to this model, a PV cell behaves akin to an ideal current generator connected in parallel to a diode and two resistances (one in series e and one in parallel) account for the losses, as shown in Figure 3.

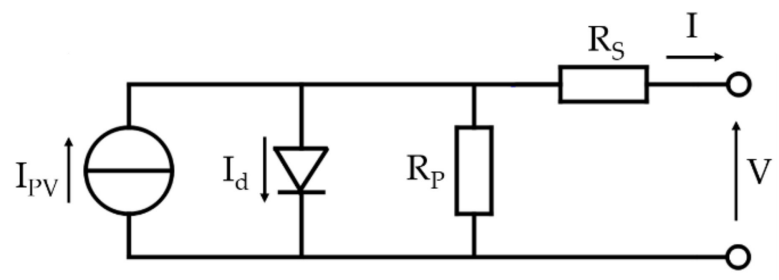

Figure 3. Single-Diode Model (SDM) equivalent circuit of a photovoltaic (PV) cell.

Taking into account that a PV generator is composed of several cells connected in series and / or parallel, Equations (1) and (2) express the relationship between output current $I$ and voltage $V$ of the module according to the SDM and allow the evaluation of DC (Direct Current) power generation:

$$
\begin{gathered}
I=I_{\mathrm{PV}}-I_{\mathrm{d}}-\frac{V+I R_{\mathrm{S}}}{R_{\mathrm{P}}}, \\
I_{\mathrm{d}}=I_{0}\left[\exp \left(\frac{q\left(V+I R_{\mathrm{S}}\right)}{a K T}\right)-1\right],
\end{gathered}
$$

where $I_{\mathrm{PV}}$ is the cell photovoltaic current, $I_{0}$ is the cell saturation current, $R_{\mathrm{S}}$ is the cell series resistance, $R_{\mathrm{P}}$ is the cell parallel resistance, $q$ is the electron charge, $a$ is the diode ideality factor, $K$ is the Boltzmann constant and $T$ is the module temperature [38]. Current $I$ is multiplied by $N_{\mathrm{P}}$ according to the number of elements in parallel and voltage $V$ is multiplied by $N_{S}$ according to the number of elements in series.

For the evaluation of $\mathrm{PV}$ power production, solar irradiance was required, as $I_{\mathrm{PV}}$ is directly proportional to it. This information was extrapolated from the IWEC file, the same used for the building and ASHP energy performance evaluation. Furthermore, the PV model built in EnergyPlus takes into account the reduction in energy generation due to solar shading thanks to the representation of the obstructions near to the facility.

The power conditioning unit for AC (Alternating Current) grid, consisting of the maximum power point tracker and the DC/AC converter [39], was represented with a simplified model according to which its efficiency is constant and equal to $97.6 \%$. Thus, the DC photovoltaic power generation, which is the output of the SDM, was reduced by this factor.

The installation of $24 \mathrm{PV}$ modules is planned with a total nominal power of $8.64 \mathrm{~kW}_{\mathrm{p}}$ [40]. Tilt $\beta$ and azimuth $\gamma$ of PV modules coincide with those of the support surfaces. Thus, $\beta$ and $\gamma$ are not the optimal ones from an energy generation point of view, but they are imposed by the building architectonic project. The modules will be installed in different arrays as follows:

- 3 modules $\left(1.08 \mathrm{~kW}_{\mathrm{p}}\right)$ on the roof of the technical room facing SE $\left(\beta=13.4^{\circ}, \gamma=-64^{\circ}\right.$ with respect to $\mathrm{S}, \mathrm{W}$ corresponding to $90^{\circ}$ ) and 3 modules on its vertical wall facing $\operatorname{SE}\left(\beta=90^{\circ}, \gamma=-64^{\circ}\right)$;

- 6 modules $\left(2.16 \mathrm{~kW}_{\mathrm{p}}\right)$ on the roof of the study room 1 facing SE $\left(\beta=13.4^{\circ}, \gamma=-64^{\circ}\right)$;

- 6 modules on the roof of the study room 2 facing a NW $\left(\beta=15^{\circ}, \gamma=116^{\circ}\right)$;

- 3 modules on the roof of the control room facing SE $\left(\beta=13.4^{\circ}, \gamma=-64^{\circ}\right)$ and 3 modules on its vertical wall facing SE $\left(\beta=90^{\circ}, \gamma=-64^{\circ}\right)$.

The above-described PV arrays will be part of three generators, providing energy to the units defined in Section 2.2.1. The modules on the external surfaces of the control room and of the technical room will be part of the $4.32 \mathrm{~kW}_{\mathrm{p}} \mathrm{PV}$ generator of unit 1 . The 6 modules on the roof of study room $1\left(2.16 \mathrm{~kW}_{\mathrm{p}}\right)$ will collect solar power for unit 2 . Finally, the modules on the roof of the study room $2\left(2.16 \mathrm{~kW}_{\mathrm{p}}\right)$ provide PV energy to unit 3 . The different nominal powers of the generators and the different tilt and azimuth angles of the 
modules provide the desired diversification of PV power profiles of the three units, which is useful for evaluating the effects of local energy sharing. For greater clarity, Figure 4 shows a graphic representation of the disposition and allocation of PV arrays.

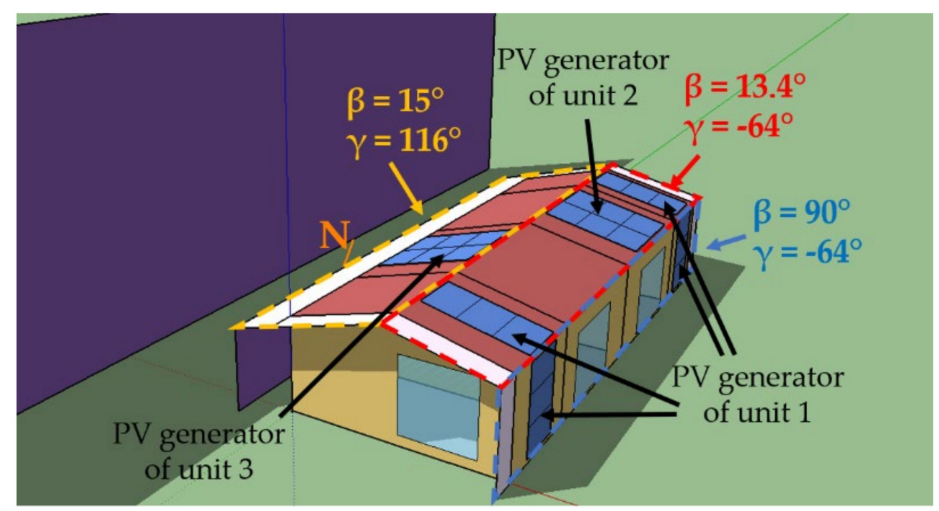

Figure 4. Disposition and allocation of PV arrays among the three generators.

\subsubsection{BESS Model}

The possibility of installing a BESS for each unit was evaluated. Several storage capacities were taken into account in order to assess their different impacts on the KPIs, defined in Section 2.3. The operation of BESSs was simulated with an energy model developed in the MATLAB ${ }^{\circledR}$ environment. The most used battery models involve the estimation of the State Of Charge (SOC). Over the years, several methods for SOC estimation, characterized by different complexities and accuracies, have been developed [41-43]. A simple and easy to implement method was used in this work, as it is sufficient for carrying out a preliminary evaluation on the impact of BESS installation. The implemented model is based on the calculation of the $S O C$ at any time instant $t$ according to the following equations:

$$
\begin{gathered}
\operatorname{SOC}(t)=\operatorname{SOC}(t-1)-\eta_{\text {batt }} \cdot \frac{P_{\text {batt }}(t) \cdot \Delta t}{C_{\text {batt }}} \quad P_{\text {batt }}(t)<0, \\
\operatorname{SOC}(t)=\operatorname{SOC}(t-1)-\frac{P_{\text {batt }}(t) \cdot \Delta t}{C_{\text {batt }}} \quad P_{\text {batt }}(t)>0,
\end{gathered}
$$

where $\operatorname{SOC}(t-1)$ is the $S O C$ at the previous time instant $t-1, \eta_{\text {batt }}$ is the charge/discharge efficiency in charging operation, $P_{\text {batt }}$ is the average power exchange in the timestep $\Delta t$ between the battery and the system $\left(P_{\text {batt }}<0\right.$ in charge and $P_{\text {batt }}>0$ in discharge $)$ and $C_{\text {batt }}$ is the battery nominal energy capacity.

In this study, batteries were charged only by PV energy and their SOC increased following Equation (3). Thus, in the case of PV energy surplus, BESS charging occurred. On the contrary, BESS was discharged according to Equation (4) when the electrical load exceeded the PV production. Charging and discharging processes have to respect two limits in order to preserve the battery life. A power limit $\left(P_{\text {bat }}<P_{\text {batt,max }}\right)$, defined in the technical specifications, is required to avoid too fast charging/discharging. When the power exceeds this threshold, it is limited to the maximum recommended value $P_{\text {batt,max }}$. The second limit is related to the energy capacity: the battery SOC must not exceed the minimum $\left(S O C \geq S O C_{\min }\right)$ and maximum $\left(S O C \leq S O C_{\max }\right)$ values, provided by the manufacturer. Any energy surplus or deficit due to the two limits led to energy exchanges between the facility and the external electrical grid (energy injections and absorptions, respectively).

The characteristics of the BESS considered in this work were provided by the datasheet of a modular lithium-ion battery on the market and are shown in Table 7. 
Table 7. Characteristics of one module of the selected lithium-ion battery.

\begin{tabular}{cc}
\hline Parameter & Value \\
\hline Nominal capacity & $2.4 \mathrm{kWh}$ \\
Usable capacity & $2.2 \mathrm{kWh}$ \\
Recommended charge/discharge current & $25 \mathrm{~A}$ \\
Average charge voltage & $53 \mathrm{~V}$ \\
Average discharge voltage & $49.25 \mathrm{~V}$ \\
\hline
\end{tabular}

A $S O C_{\min }=4 \%$ and a $S O C_{\max }=96 \%$ were assumed, in compliance with the characteristics in Table 7 and the typical values for the lithium-ion technology. An $\eta_{\text {bat }}=96 \%$ was considered. The simulated nominal capacities of each BESS were 0 (i.e., no battery), $2.4,4.8,7.2$ and $9.6 \mathrm{kWh}$ and an initial SOC of $50 \%$ was set for the three batteries in all the simulations.

\subsubsection{Model Integration}

The methodology followed for the development of the energy models of the PVZEN facility is summarized in Figure 5. Following a top-down approach, the global model of the building was developed at three distinct levels: on the top level, the thermoenergy model of the building was defined through the OpenStudio SketchUp plug-in and EnergyPlus. The results obtained from the building model allowed us to develop a second level of detail, modelling the main energy systems-the PV generators, via EnergyPlus, and the heat pump, modelled in the MATLAB ${ }^{\circledR}$ environment. Finally, the results obtained in terms of load and production of electricity were integrated for the development of the model of storage batteries for the facility. The simulations developed in each level of the model were performed with the same timestep, which was equal to $15 \mathrm{~min}$. This value was considered as the most appropriate for evaluating both thermal and electrical behaviors (photovoltaic production, use of storage batteries).

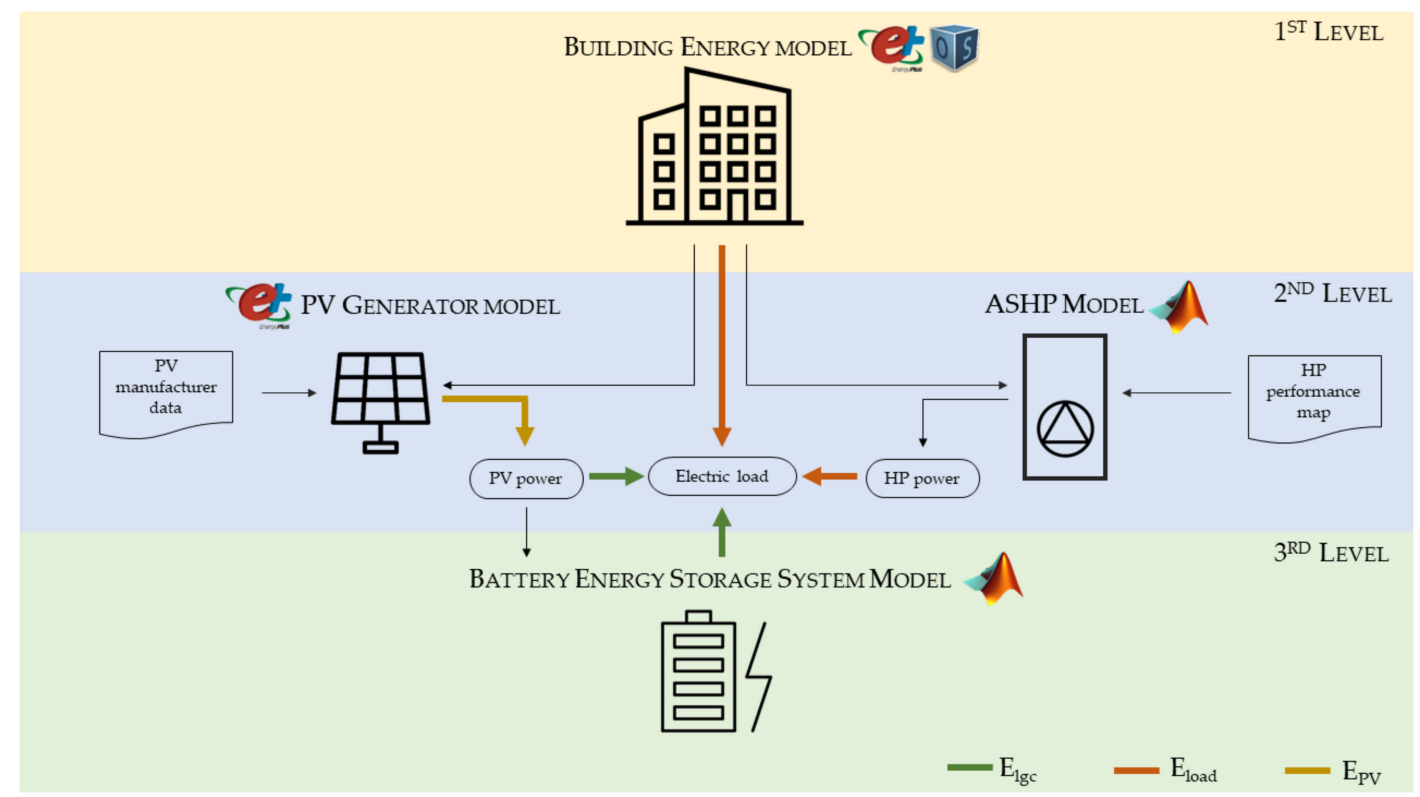

Figure 5. PVZEN facility modelling approach.

In addition to showing the levels of development of the numerical model, Figure 5 highlights the energy flows exchanged between the simulation modules. The energy flows that represent the locally generated and consumed energy $\left(E_{\operatorname{lgc}}\right)$, the total electrical load $\left(E_{\text {load }}\right)$ and the energy produced by the photovoltaic generator $\left(E_{\mathrm{PV}}\right)$ have been highlighted in green, orange and yellow, respectively. These energy flows are responsible 
for the definitions of the key performance indicators, addressed and discussed in the next subsection.

\subsection{Key Performance Indicators (KPIs)}

To describe the thermal performance of the case study building, the monthly and specific energy needs were analyzed, both in winter and summer conditions. In addition, the entire building was characterized by the energy signature method, built on the basis of the hourly results of the numerical simulation following the approach proposed by the European standard EN 15378-3:2017 [44].

The overall electrical performance of the building and HVAC system is instead represented by two KPIs that quantify the interaction between the test facility and the external electrical grid. Self-sufficiency and self-consumption were considered suitable for this purpose.

Self-sufficiency was calculated according to the following equation:

$$
S S(\%)=\frac{E_{\operatorname{lgc}}}{E_{\text {load }}} \times 100,
$$

where $E_{\operatorname{lgc}}$ is the PV energy produced and simultaneously consumed or stored and then supplied by the BESS, while $E_{\text {load }}$ is the total consumed energy [45]. It quantifies the degree of autonomy of the facility in terms of energy absorption from the external grid and its value is between $0 \%$ and $100 \%$. The higher the self-sufficiency, the lower the energy absorption from the grid required to fulfil the energy demand.

Self-consumption was calculated according to the following formula:

$$
S C(\%)=\frac{E_{\operatorname{lgc}}}{E_{\mathrm{PV}}} \times 100
$$

where $E_{\operatorname{lgc}}$ is the PV energy produced and simultaneously consumed or stored and then supplied by the BESS, while $E_{\mathrm{PV}}$ is the energy produced by the PV system [45]. It quantifies the PV energy quota consumed locally, including the energy stored in the BESS for a later use. Its value is between $0 \%$ and $100 \%$. The higher the self-consumption, the lower the injections in the grid due to overproduction or mismatch between local energy generation and consumption.

For greater clarity, the energy flows involved in the calculation of self-sufficiency and self-consumption are highlighted using different colors in Figure 5.

\subsection{Simulation Scenarios}

The models described in Sections 2.2.1-2.2.3 permitted the obtention of the power profiles of PV production and electrical load of the three units. Then, some simulation scenarios were defined in order to compare these profiles and determine the value of the KPIs described in the previous subsection.

Two scenarios have been selected and analyzed. In the first one, the three units can exchange energy only with the external electrical grid in the case of energy surplus or deficit. Firstly, a reference case with PV systems and no batteries was studied, as it is the most diffused situation at present. Then, the possibility of installing BESSs was evaluated. Charge and discharge profiles of batteries were obtained following the logic described in Section 2.2.4. Finally, the energy exchange between the facility and the grid was evaluated. The KPIs were calculated on an annual basis and they were useful for properly sizing the BESSs.

In the second simulation scenario, the same analysis was carried out considering that the units can share the self-generated energy among them. The logic adopted in this second scenario aims to maximize the identified KPIs. For this reason, the sharing of energy between the individual units has priority over the exchange with the external electricity grid. In the logic adopted, a control on energy consumption was implemented, giving priority to self-consumption first by consuming the energy produced by the PV generators 
and then by using the batteries. In the absence of energy through these methods, energy exchange with the external grid is allowed.

\section{Results}

\subsection{Thermal Energy Performance}

The thermal performance of the test facility is the result of the combination of a highperformance envelope (summarized in Table 3) and a fully electric HVAC system (see Section 2.2.2). The heating and cooling power loads of the building are shown in Figure 6 by means of the annual thermal load in winter (a) and in summer conditions (b). The figure shows the cumulative curves of heating and cooling loads, both for the entire building (continuous lines) and for the single units (dashed lines). The trend of the required power is almost the same for units 2 and 3 (same intended use), while it differs for unit 1.
Heating
Cooling
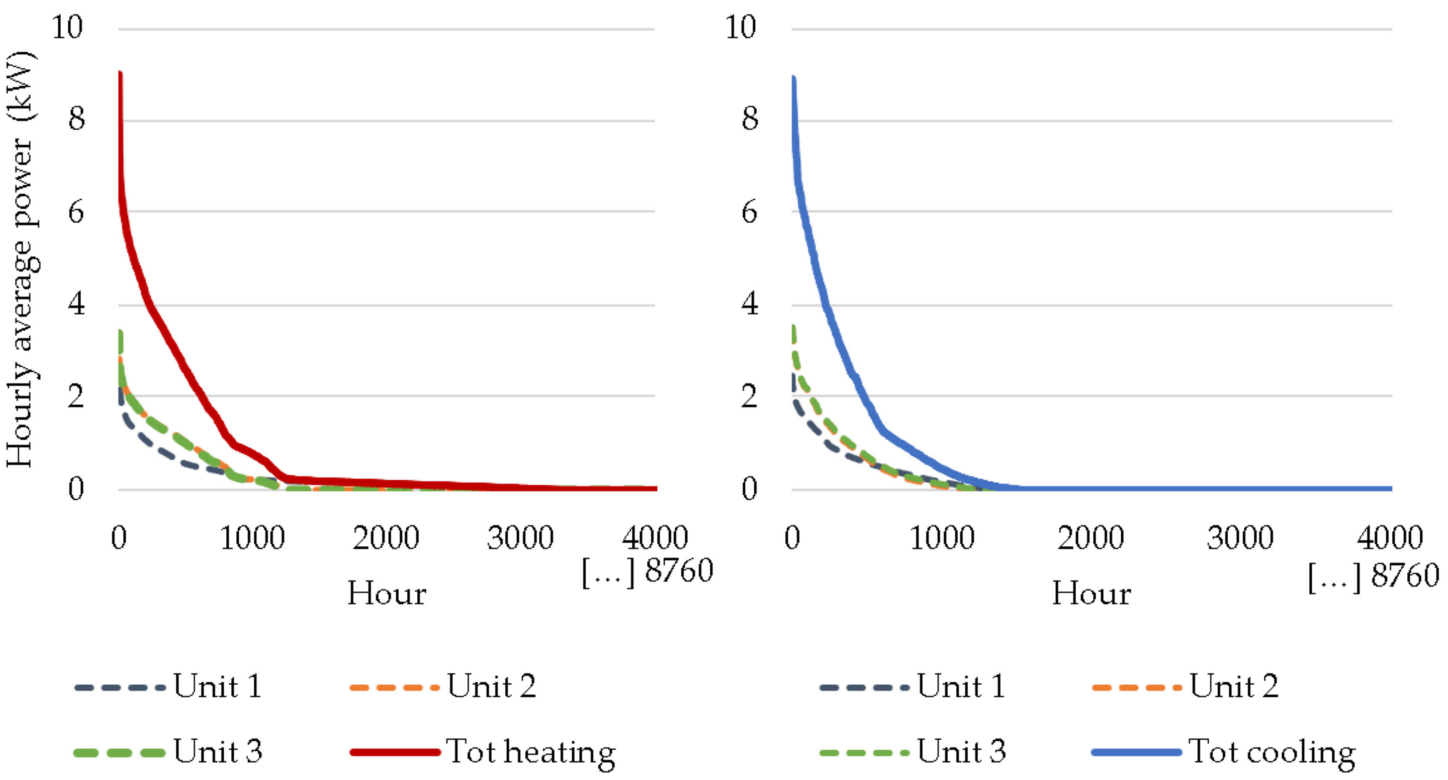

(a)

(b)

Figure 6. Cumulative curves of heating (a) and cooling (b) loads of the various units of the whole building.

When considering the annual behavior of the building in terms of energy needs, Table 8 reports the specific annual values for heating, cooling and electricity needs. From the results obtained, the test facility can be classified as a high-performance building, perfectly in line with the heating and cooling needs of the new European nZEBs [46]. The greatest energy impact is due to electricity consumption, which is considerable due to the work equipment and appliances installed in the facility, as well as the mechanical ventilation system.

Table 8. Specific heating, cooling and electricity needs of the three units.

\begin{tabular}{|c|c|c|c|}
\hline Unit & $\begin{array}{c}\text { Heating Need } \\
\left(\mathrm{kWh}_{\mathrm{th}} / \mathrm{m}^{2}\right)\end{array}$ & $\begin{array}{c}\text { Cooling Need } \\
\left(\mathbf{k W h} \mathrm{th} / \mathrm{m}^{2}\right)\end{array}$ & $\begin{array}{l}\text { Electricity Need } \\
\quad\left(\mathrm{kWh}_{\mathrm{el}} / \mathrm{m}^{2}\right)\end{array}$ \\
\hline Unit 1 & 27.26 & 21.11 & 16.12 \\
\hline Unit 2 & 35.54 & 32.05 & 49.32 \\
\hline Unit 3 & 36.77 & 30.30 & 49.32 \\
\hline Whole building & 32.85 & 27.43 & 36.97 \\
\hline
\end{tabular}

The thermal behavior of the test facility was additionally characterized by the energy signature method, applied following the EN 15378-3:2017 standard [44]. The results, shown 
in Figure 7 in both winter (a) and summer (b) conditions, represent the average hourly heating/cooling loads or the electric power required by the building as a function of the dry bulb outside temperature. With the heating and cooling hourly loads (data point reported in red and blue, respectively), a linear regression was determined with satisfactory results $\left(R^{2}>0.72\right)$ in both cases. The figure also shows the energy signature for the corresponding electrical power of the HVAC system (i.e., the ASHP), represented by the yellow dots. In this case, the behavior of the ASHP is more accurately approximated by a polynomial second-degree regression, reaching $\mathrm{R}^{2}$ values higher than 0.80 , demonstrating the strong dependence of the HVAC system on the outside temperature.

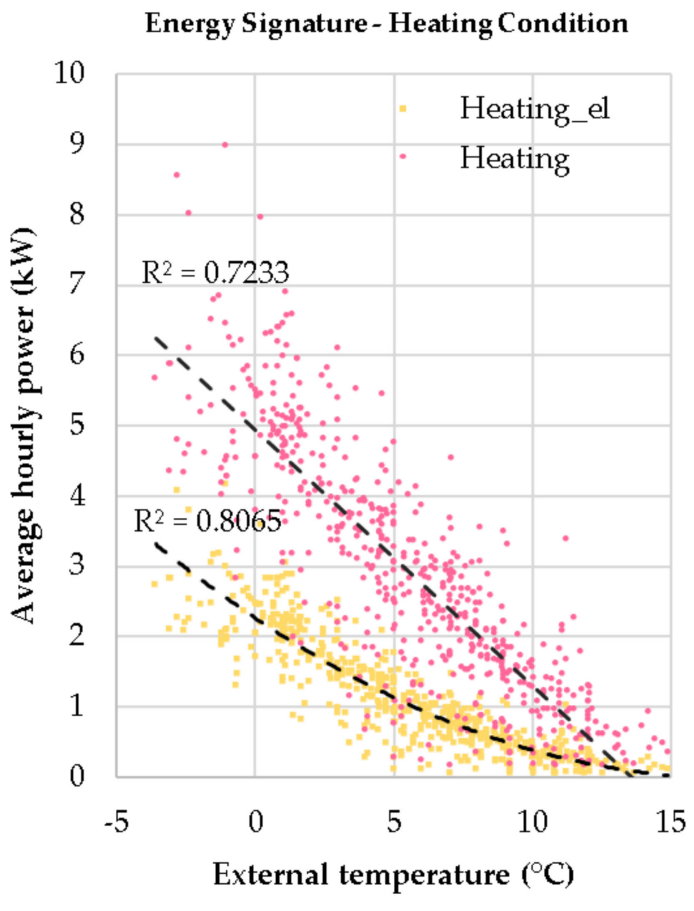

(a)

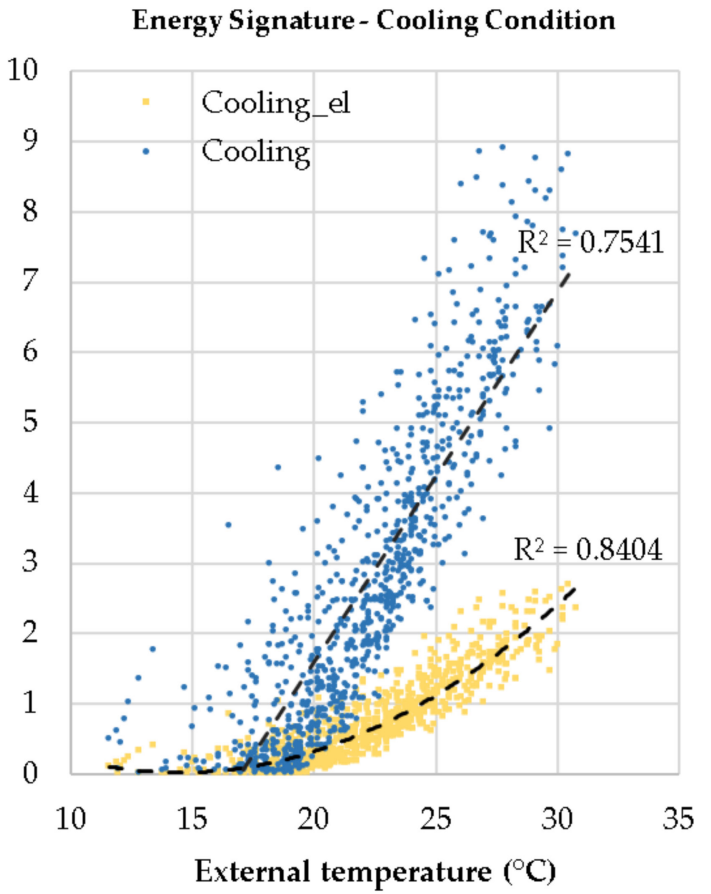

(b)

Figure 7. PVZEN facility energy signature in heating (a) and cooling (b) conditions.

\subsection{Electrical Energy Performance}

The PV generation and the electricity consumption of the facility are the result of a dynamic energy simulation, which allowed the obtention of power profiles and to appreciate the daily and seasonal variability of production and consumption. The comparison between production and consumption profiles was essential for the calculation of the selected KPIs. Indeed, both self-sufficiency and self-consumption require knowledge of whether PV energy is directly consumed or stored in batteries in each time interval. Figures 6 and 7 show examples of production $\left(P_{\mathrm{PV}}\right)$ and consumption $\left(P_{\text {load }}\right)$ power profiles of each unit in a typical winter and summer week, respectively.

Power profiles in Figures 8 and 9 show that the energy consumption of this university facility is higher in daylight hours, optimally matching with PV generation as expected. However, the local use of PV energy can be enhanced, for example, through the installation of BESSs. In this way, it is possible to increase the facility's self-sufficiency and selfconsumption, as PV energy surplus produced during the central hours of the day could be stored to meet the evening energy demand. Furthermore, the production surplus of unit 1 could be used locally by allowing the energy sharing among the units, in particular in winter when the energy deficits of units 2 and 3 occur during the hours characterized by the highest solar irradiation (see Figure 8). 

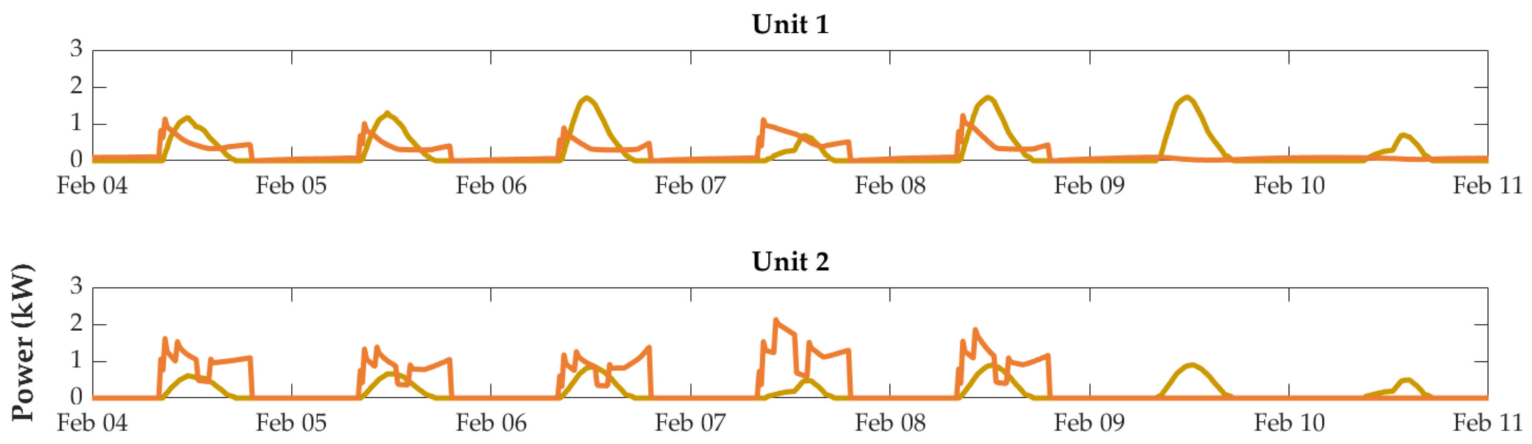

Unit 3

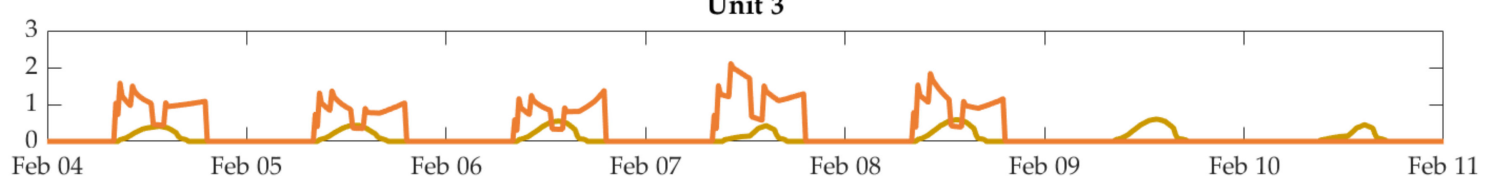

$$
-\mathrm{P}_{\mathrm{PV}} \longrightarrow \mathrm{P}_{\text {load }}
$$

Figure 8. PV production and consumption power profiles of a typical winter week.
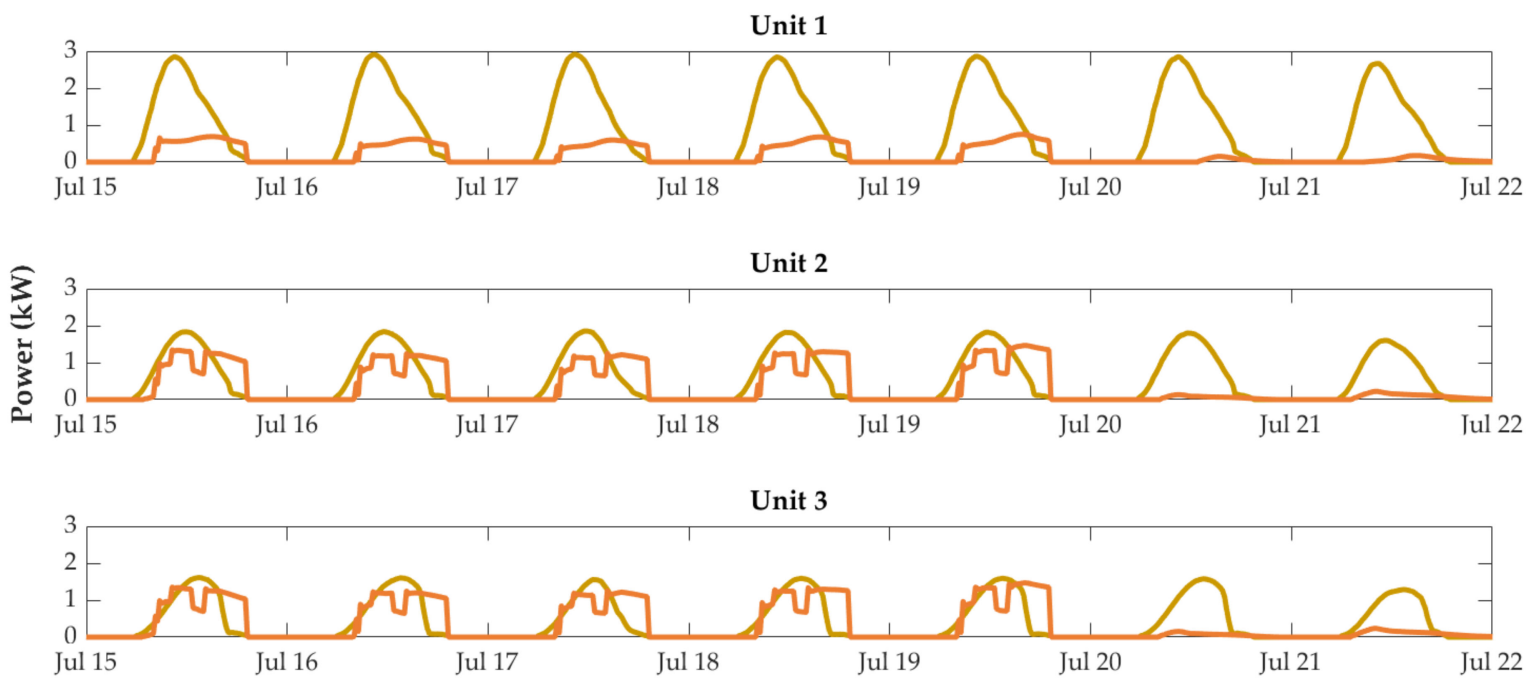

$$
-\mathrm{P}_{\mathrm{PV}} \longrightarrow \mathrm{P}_{\text {load }}
$$

Figure 9. PV production and consumption power profiles of a typical summer week.

Through the energy simulation, an annual PV generation of $7611 \mathrm{kWh}$ and an annual electricity consumption of $5541 \mathrm{kWh}$ were estimated. The heat pump electricity consumption accounts for $35 \%$ of the total annual consumption and was distributed among the units proportionally to their heating and cooling demands. Table 9 shows the contribution of each unit to the total energy production and consumption.

Table 9. Annual PV generation and energy consumption of the three units.

\begin{tabular}{ccc}
\hline Unit & Annual PV Generation & Annual Energy Consumption \\
\hline Unit 1 & $3642 \mathrm{kWh}$ & $1180 \mathrm{kWh}$ \\
Unit 2 & $2270 \mathrm{kWh}$ & $2181 \mathrm{kWh}$ \\
Unit 3 & $1699 \mathrm{kWh}$ & $2181 \mathrm{kWh}$ \\
\hline
\end{tabular}




\subsection{First Scenario}

In the first scenario, the installation of three identical energy storage systems coupled to each PV generator was analyzed. The results in terms of self-sufficiency and selfconsumption are shown in Table 9, where the BESS capacity per unit is the energy capacity of each battery system-i.e., the total storage capacity installed in the facility is three times this value. The $S S$ and $S C$ are annual values, obtained by calculating the total $E_{\mathrm{PV}}, E_{\text {load }}$ and $E_{\operatorname{lgc}}$ of the facility and using Equations (5) and (6), respectively.

BESSs significantly affect the local consumption of the energy generated by PV systems. Indeed, as shown in Table 10, an increase of $32 \%$ in SS and SC is due to the installation of a $2.4 \mathrm{kWh}$ battery for each unit (second row) compared to the case without batteries (first row). The gradual increase in battery capacity (third-fifth rows) led to an increase in self-sufficiency and self-consumption, but their rate of change decreased-SS and SC with three storages of $4.8 \mathrm{kWh}$ are $7 \%$ higher than the $2.4 \mathrm{kWh}$ case, the KPIs with three batteries of $7.2 \mathrm{kWh}$ increased by $4 \%$ compared to the $4.8 \mathrm{kWh}$ case and, finally, the increments of $S S$ and $S C$ with capacities of $9.6 \mathrm{kWh}$ resulted in a $3 \%$ increase compared to the $7.2 \mathrm{kWh}$ case.

Table 10. Main results of the first scenario.

\begin{tabular}{ccc}
\hline BESS Capacity per Unit (kWh) & SS & SC \\
\hline 0 & $45 \%$ & $33 \%$ \\
2.4 & $60 \%$ & $43 \%$ \\
4.8 & $64 \%$ & $46 \%$ \\
7.2 & $66 \%$ & $48 \%$ \\
9.6 & $68 \%$ & $49 \%$ \\
\hline
\end{tabular}

Figures 10 and 11 show the power profiles of a typical winter and summer day in the event that a battery of $2.4 \mathrm{kWh}$ being installed in each unit. In addition to PV generation $\left(P_{\mathrm{PV}}\right)$ and electrical load $\left(P_{\text {load }}\right)$, the power exchange between the units and the batteries $\left(P_{\mathrm{BESS}}\right)$ and between the units and the external electrical grid $\left(P_{\text {grid }}\right)$ are represented. The generator convention was adopted for both batteries and the grid- $P_{\text {BESS }}$ is positive if the battery is discharging and negative if the battery is charging and $P_{\text {grid }}$ is positive if it is absorbed from the grid, vice versa if it is injected into the grid.
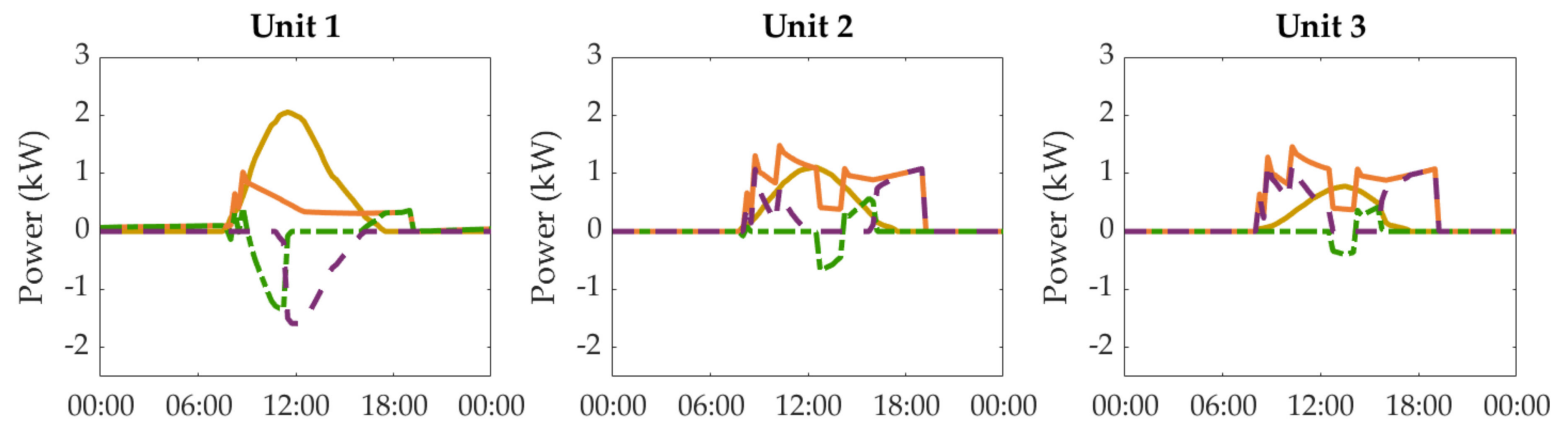

$$
-\mathrm{P}_{\mathrm{PV}} \longrightarrow \mathrm{P}_{\text {load }}---\mathrm{P}_{\text {BESS }}--^{\mathrm{P}_{\text {grid }}}
$$

Figure 10. Power profiles of PV generation, electrical load, Battery Energy Storage System (BESS) charge/discharge and grid absorptions/injections during a typical winter day for the three units. 

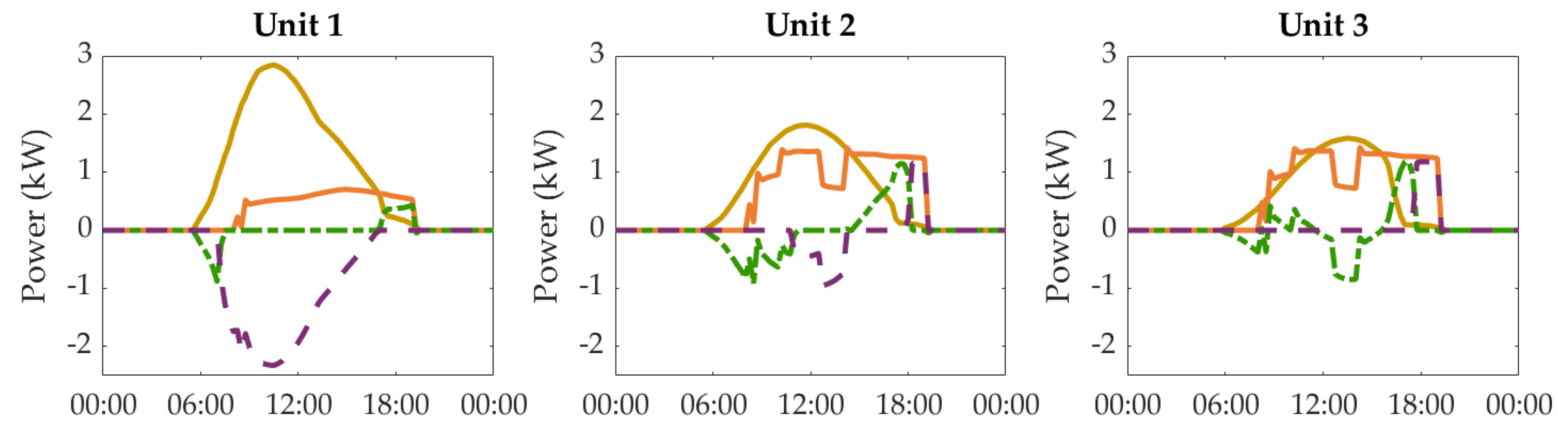

$$
-\mathrm{P}_{\mathrm{PV}}-\mathrm{P}_{\text {load }}---\mathrm{P}_{\mathrm{BESS}}-{ }^{\mathrm{P}} \mathrm{P}_{\text {grid }}
$$

Figure 11. Power profiles of PV generation, electrical load, BESS charge/discharge and grid absorptions/injections during a typical summer day for the three units.

Figures 10 and 11 point out the diversification of energy generation and consumption profiles between the units. During a typical sunny day, unit 1 is characterized by the highest $\mathrm{PV}$ production and the lowest energy consumption in both winter and summer seasons. Unit 2 and unit 3 have similar load profiles but differ in terms of energy production, as PV modules have different orientations and the modules of unit 3 are shaded in the late afternoon. Thus, it was reasonable to analyze a scenario in which the local energy sharing is allowed in order to improve the self-sufficiency and the self-consumption of the facility.

\subsection{Second Scenario}

In the second scenario, the possibility of increasing the local use of self-generated renewable energy by enabling the energy sharing among the facility units was studied according to the approach discussed in Section 2.4. In addition, the installation of batteries was considered, similarly to the first scenario. The results obtained are reported in Table 11.

Table 11. Main results of the second scenario.

\begin{tabular}{ccc}
\hline BESS Capacity per Unit (kWh) & SS & SC \\
\hline 0 & $50 \%$ & $36 \%$ \\
2.4 & $67 \%$ & $49 \%$ \\
4.8 & $71 \%$ & $52 \%$ \\
7.2 & $73 \%$ & $53 \%$ \\
9.6 & $75 \%$ & $54 \%$ \\
\hline
\end{tabular}

The local energy exchange increases the facility consumption of PV energy: SS and $S C$ increase by $11 \%$ compared to the case in which units are independent from the energy point of view (Table 10, first row). However, the addition of batteries has a greater impact. Indeed, three energy storages of $2.4 \mathrm{kWh}$ (Table 11, second row) increase $S S$ and SC by $34 \%$ compared to the case with no batteries (Table 11, first row) and by $48 \%$ compared to the case with no batteries and energy independent units (Table 10, first row). Additionally, in this second scenario, the increase in BESS size (Table 11, third-fifth rows) enhances self-sufficiency and self-consumption, but the KPI rate of change decreases.

In Figure 12, the power profiles of a typical winter (a) and summer (b) day in the event that a battery of $2.4 \mathrm{kWh}$ has been installed in each unit are shown. For the evaluation of the KPIs of the second scenario, the aggregate power profiles of PV generation and consumption of the three units were compared. In this way, the SS and SC of the facility have been maximized as the use of aggregate profiles allowed us to assume that the energy sharing among the local users always has priority over the exchange with the external grid. 


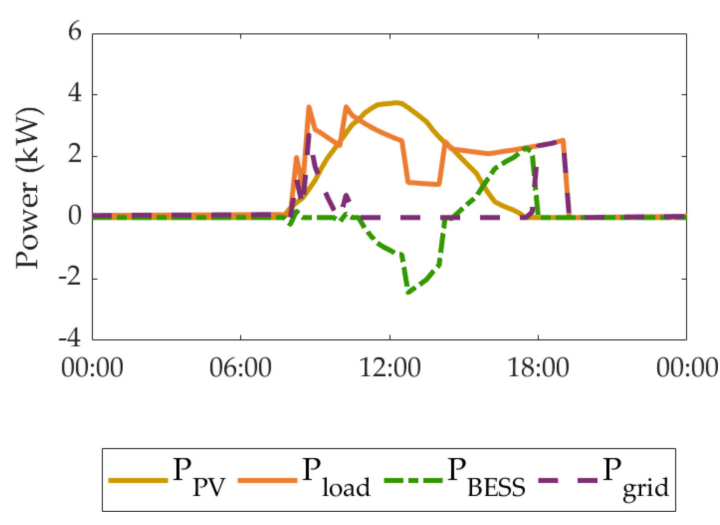

(a)

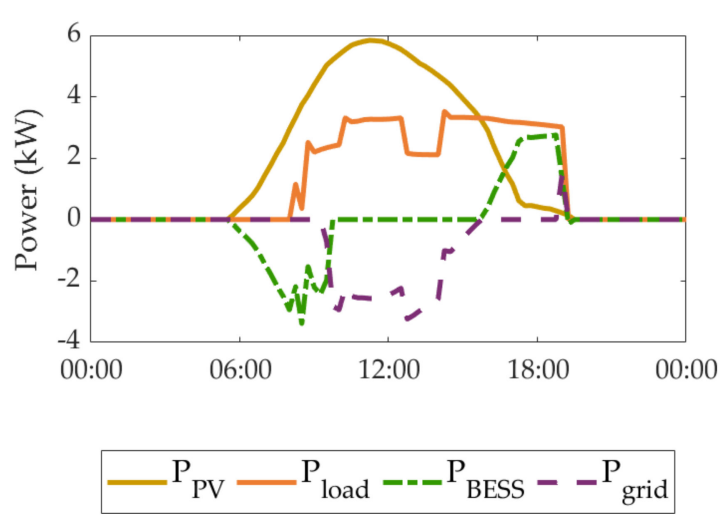

(b)

Figure 12. Power profiles of PV generation, electrical load, BESS charge/discharge and grid absorptions/injections during a typical winter (a) and summer (b) day for the facility.

As shown in Figure 12, it is possible to approach $100 \%$ self-sufficiency in sunny summer days thanks to local energy sharing and storage. During winter, instead, power absorptions from the grid are still necessary to cover the energy demand of the whole facility. However, a better use of the PV energy produced in the highest solar irradiation hours is provided by both energy sharing and BESSs even in the cold season. In particular, the figure points out that all the energy surplus is stored in the batteries, reducing the absorption from the grid in the afternoon.

In terms of mismatch between power production and consumption, the critical hours of the day occur in the morning and in the afternoon. In this scenario, these critical moments determine the winter energy dependence on the grid-winter daylight hours are fewer than the summer ones and batteries can contribute to the reduction in power absorptions from the grid only in the afternoon as they are completely discharged in the morning. During summer, the hours of mismatch between production and consumption occur in the late afternoon. However, the energy stored in the BESSs is sufficient for completely or largely covering the demand.

\section{Discussion and Conclusions}

The analysis of the two scenarios demonstrates that the local use of PV generation can be increased through the installation of BESSs and/or allowing the energy sharing among the three units of the facility. In both scenarios, the increase in energy capacity of the three batteries implies an enhancement of self-sufficiency and self-consumption. However, there is not a direct proportionality between the energy capacity of batteries and the selected KPIs - the gradual increase in storage capacity affects the increase in self-sufficiency and self-consumption less and less. Therefore, it is reasonable to increase the size of BESSs up to the energy capacity value that provides a significant improvement in the KPIs, justifying the increase in the investment cost of energy storages.

The KPIs, resulting from the analysis of the two scenarios and shown in Tables 10 and 11, are plotted in Figure 13 in order to provide a graphic representation of self-sufficiency and self-consumption as a function of BESS capacity per unit.

As shown in Figure 13, in the first scenario, the optimal battery size per unit is $2.4 \mathrm{kWh}$, as it provides the greatest KPIs improvement, achieving an $S S$ of $60 \%$ and a $S C$ of $43 \%$. Doubling the energy capacity causes an increment of only $7 \%$ for the KPIs. Even in the second scenario, the optimal size of each battery results $2.4 \mathrm{kWh}$. A further increment to $4.8 \mathrm{kWh}$ per unit provides an increase of $6 \%$ in the KPIs. Even if the optimal BESS capacity per unit is the same in both scenarios, the solution that involves the local energy sharing produces higher values for KPIs—SS and SC are $12 \%$ higher, achieving $67 \%$ and $49 \%$, respectively. 


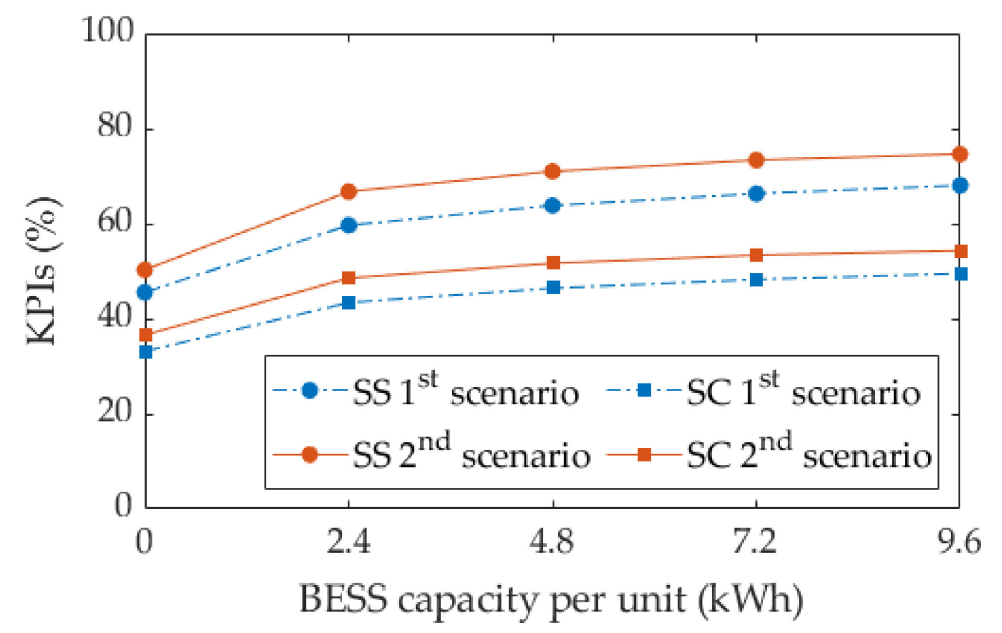

Figure 13. Annual self-sufficiency and self-consumption of the facility as a function of BESS capacity per unit in the two scenarios.

To investigate the optimal battery size to be installed in the facility, a preliminary economic analysis on BESSs was carried out, taking into consideration the first simulation scenario. For this scenario, the costs relating to the initial investment and the economic electrical expenses of the facility were identified.

The assumptions supporting this analysis are summarized in Table 12; some data were provided by the battery manufacturer (initial cost and expected lifespan) and some data are derived from a market analysis (average cost of electricity, discount rate). A 50\% tax deduction over 10 years was also assumed on the first purchase of batteries to take into consideration the tax incentives frequently adopted by European states.

Table 12. Assumptions for economic analysis.

\begin{tabular}{ccc}
\hline Data & Value & Unit \\
\hline Investment cost (from manufacturer) & 340 & EUR $/ \mathrm{kWh}$ \\
Batteries lifespan (from manufacturer) & 11 & years \\
Average electricity cost & 0.15 & EUR $/ \mathrm{kWh}$ \\
Discount rate & 4 & $\%$ \\
Tax deduction (over 10 years) & 50 & $\%$ \\
\hline
\end{tabular}

Taking into consideration the assumptions described and the PV electricity selfconsumed thanks to the batteries or absorbed from the external grid, it was possible to study the trend of the cumulative discounted cash flows relating to the BESS systems. Figure 14 shows the comparison between the cumulative discounted cash flows of the first scenario, with different BESS capacities installed per unit. The analysis shown in the figure has been extended to 25 years and was assumed as the useful life cycle of the PV system. The different BESS capacities are compared with the case without batteries installed (no BESS), for which only the expense incurred for the purchase of electricity from the grid was considered, after deducting the PV self-consumed energy.

From this figure it is evident that the impact of the initial investment cost has a considerable weight, especially since it is repeated every 11 years during the PV system's lifespan. The positive effect of tax deductions is visible in the first 10 years. From the graphical comparison of the different cases, the only one to economically compete with the scenario without batteries is the one with the lowest BESS capacity per unit. This analysis supports the decision to indicate the lowest battery capacity as the most interesting, demonstrating that the investment in BESS is not supported by competitive prices and/or government policies yet. The economic analysis produced similar results when applied to the second scenario, but has not been reported for the sake of brevity. 


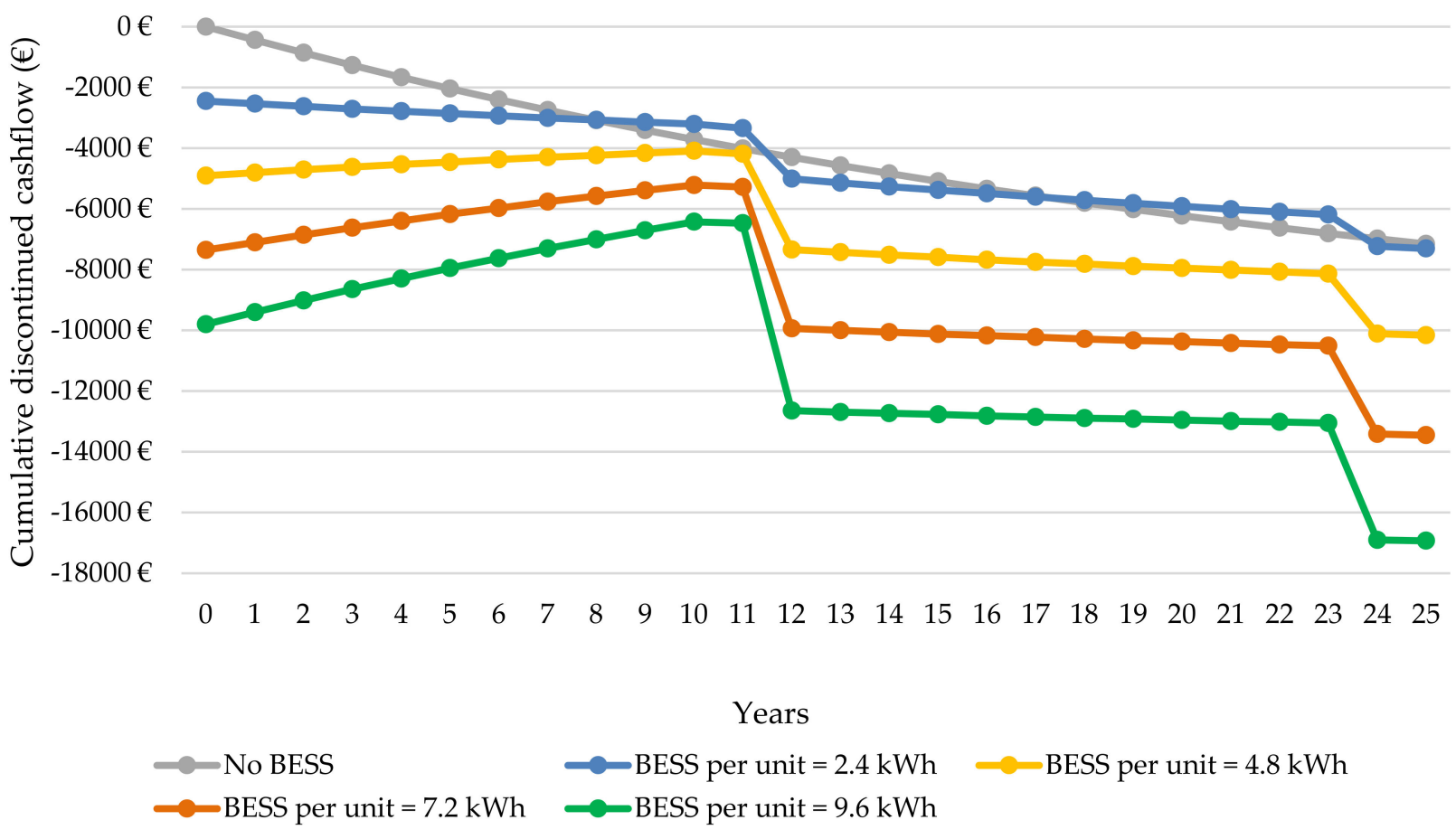

Figure 14. Comparison of cumulative discounted cash flows relating to the BESSs system for the first scenario with different BESS capacities installed during the PV system's expected lifespan.

The analysis of energy exchange between the facility units carried out within the second scenario can be considered as a simplified approach to the new-born concept of energy community, defined by the European Directives 2018/2001/EU and 2019/944/EU. Indeed, the adopted approach can be applied on a larger scale, i.e., considering several interconnected buildings, in future energy communities in which the self-consumption and the exchange of the energy produced from local renewable sources are promoted.

A dynamic simulation study such as the one presented in this work is essential for evaluating and analyzing the energy behavior of a test facility in order to optimally design it. The assessment of design solutions for energy systems such as PV generators and heat pumps is less accurate if carried out on a monthly or annual basis. Indeed, their operation is strongly affected by the variability of climatic conditions (air temperature, solar irradiation, wind speed) and the variation of the facility thermal demand depending on the hour of the day, the number of occupants and operational equipment. Moreover, the self-sufficiency and self-consumption evaluations require the study of daily energy profiles because a comparison between energy production and consumption over short time intervals is needed.

After its construction, the test facility may be relevant for the validation of numerical models, such as the one developed in this work, and for further research and educational purposes. Since it is placed in a university campus, the facility could be used and studied by university students. Thermophysical, electrical and electronic experiments could be conducted, supported by a detailed knowledge of the construction and plant features of the facility and by the possibility of monitoring it.

A key aspect of the PVZEN project, within which the analyzed test facility was conceived, is the quite innovative approach adopted to evaluate the energy behavior of the test facility with optimized building physics and integrated energy systems. This type of approach requires more effort and the engagement of experts in different research fields and domains. Examples available in the literature show that most of the studies on facilities built for research purposes are aimed at monitoring or simulating the performance of technology solutions, such as selected types of heating and cooling terminals, ventilation systems and advanced façades in a real or realistic context. Fewer studies have been conducted using 
an integrated multidisciplinary approach, such as the one adopted in PVZEN, aimed at considering the mutual relationships between the parameters affecting the energy demand and the others impacting the energy supply, thus exploring the entire nZEB design space, providing methods, tools and data for advanced optimization processes.

Author Contributions: Conceptualization, E.F., V.S. and F.S.; methodology, A.A., M.B., E.F. and F.S.; investigation, A.A., M.B., E.F., V.S. and F.S.; data curation, A.A. and M.B.; writing-original draft preparation, A.A. and M.B.; writing-review and editing, A.A., M.B. and E.F.; visualization, A.A. and M.B.; supervision, E.F. and F.S.; project administration, V.S. and F.S. All authors have read and agreed to the published version of the manuscript.

Funding: The research project defined by the acronym PVZEN has been internally funded by the Politecnico di Torino University via the so-called "Distributed Structural Funding" in 2018 and 2019. Part of the activities presented in this paper were carried out within the framework of the Research Project of Relevant National Interest (PRIN) "The energy FLEXibility of enhanced HEAT pumps for the next generation of sustainable buildings (FLEXHEAT)" (PRIN 2017, Sector PE8, Line A, Grant $n$. 33), funded by the Italian Ministry of Education, University and Research (MIUR).

Institutional Review Board Statement: Not applicable.

Informed Consent Statement: Not applicable.

Data Availability Statement: Data available on request due to restrictions. The data presented in this study are available on request from the corresponding author. The data are not publicly available due to privacy reasons.

Acknowledgments: The authors wish to acknowledge the valuable contributions to the PVZEN project of all the research group consisting of: DENERG branch (Capozzoli A., Carpaneto E., Di Leo P., Fabrizio E., Ferraris L., Fracastoro G., Piglione F., Pons E., Russo A., Serra V., Simonetti M., and Spertino F.); DAD branch (Callegari G. and Bosia D.); DET branch (Carullo A., Corbellini S., and Vallan A.). The design specifications of the PVZEN facility were defined within the Master "Architettura delle Costruzioni in legno", 1st edition, by the student team composed by M. Ansalone, G. Assenza, L. Macario Ban, M. Cuoppolo, E. Falappa, N. Farina, E. Fasce, E. Follegatti, E. C. Forestieri, M. Meloni, M. Montis, G. Preda, C. Santamaria, G. Sciortino, A. Selvaggio, D. G. Serra, and C. Zappia, under the supervision of G. Ambrosini, G. Callegari, M. Guiglia, A. Perron Cabus, V. Serra, and P. Simeone.

Conflicts of Interest: The authors declare no conflict of interest.

\section{References}

1. European Union. Directive 2010/31/EU of the European Parliament and of the Council of 19 May 2010 on the Energy Performance of Buildings. Off. J. Eur. Union 2010, L153, 13-35.

2. European Union. Directive 2018/844/EU of the European Parliament and of the Council of 30 May 2018 Amending Directive 2010/31/Eu On The Energy Performance of Buildings and Directive 2012/27/Eu on Energy Efficiency. Off. J. Eur. Union 2018, L156, 75-91.

3. Pappalardo, M.; Reverdy, T. Explaining the Performance Gap in a French Energy Efficient Building: Persistent Misalignment Between Building Design, Space Occupancy and Operation Practices. Energy Res. Soc. Sci. 2020, 70, 101809. [CrossRef]

4. Fabrizio, E. Zero Energy Buildings: A Reached Target or a Starting Point? Appl. Sci. 2020, 10, 512. [CrossRef]

5. Bilardo, M.; Ferrara, M.; Fabrizio, E. Performance assessment and optimization of a solar cooling system to satisfy renewable energy ratio (rer) requirements in multi-family buildings. Renew. Energy 2020, 155, 990-1008. [CrossRef]

6. Bot, K.; Aelenei, L.; Da Glória Gomes, M.; Silva, C.S. Performance assessment of a building integrated photovoltaic thermal system in mediterranean climate-A numerical simulation Approach. Energies 2020, 13, 2887. [CrossRef]

7. Monetti, V.; Davin, E.; Fabrizio, E.; André, P.; Filippi, M. Calibration of building energy simulation models based on optimization: A Case Study. Energy Procedia 2015, 78, 2971-2976. [CrossRef]

8. Ferrara, M.; Prunotto, F.; Rolfo, A.; Fabrizio, E. Energy demand and supply simultaneous optimization to design a nearly zero-energy house. Appl. Sci. 2019, 9, 2261. [CrossRef]

9. Ascione, F.; De Masi, R.F.; De Rossi, F.; Ruggiero, S.; Vanoli, G.P. Optimization of building envelope design for nzebs in mediterranean climate: Performance analysis of residential case study. Appl. Energy 2016, 183, 938-957. [CrossRef]

10. Bilardo, M.; Fraisse, G.; Pailha, M.; Fabrizio, E. Design and experimental analysis of an integral collector storage (ics) prototype for dhw production. Appl. Energy 2020, 259, 114104. [CrossRef] 
11. Võsa, K.V.; Ferrantelli, A.; Kurnitski, J. Experimental study of radiator, underfloor, ceiling and air heater systems heat emission performance in tut nzeb test facility. E3s Web Conf. 2019, 111, 04005. [CrossRef]

12. Võsa, K.V.; Ferrantelli, A.; Kurnitski, J. Annual performance analysis of heat emission in radiator and underfloor heating systems in the European reference room. E3s Web Conf. 2019, 111, 04009. [CrossRef]

13. Thalfeldt, M.; Simson, R.; Kurnitski, J. The Effect of hydronic balancing on room temperature and heat pump efficiency of a building with underfloor Heating. Energy Procedia 2016, 96, 467-477. [CrossRef]

14. Andriamamonjy, A.L.; Klein, R. A Modular, open system for testing ventilation and cooling strategies in extremely low energy lecture rooms. In Proceedings of the 36th Aivc-5th Tightvent-3rd Venticool 2015, Madrid, Spain, 23-24 September 2015.

15. Goia, F.; Bianco, L.; Perino, M.; Serra, V. Energy performance assessment of and advanced integrated façade through experimental data analysis. Energy Procedia 2014, 48, 1262-1271. [CrossRef]

16. Liu, M.; Wittchen, K.B.; Heiselberg, P.K. Verification of a simplified method for intelligent glazed façade design under different control strategies in a full-scale façade test facility-preliminary results of a south facing single zone experiment for a limited summer period. Build. Environ. 2014, 82, 400-407. [CrossRef]

17. Dama, A.; Angeli, D. Wind and buoyancy driven natural ventilation in double skin façades. Int. J. Vent. 2016, 15, 288-301. [CrossRef]

18. Le Dréau, J.; Heiselberg, P.; Jensen, R.L. Experimental investigation of the influence of the air jet trajectory on convective heat transfer in buildings equipped with air-based and radiant cooling systems. J. Build. Perform. Simul. 2015, 8, 312-325. [CrossRef]

19. Le Dréau, J.; Heiselberg, P.; Jensen, R.L. A full-scale experimental set-up for assessing the energy performance of radiant wall and active chilled beam for cooling buildings. Build. Simul. 2015, 8, 39-50. [CrossRef]

20. The European Portal for Energy Efficiency in Buildings. Efficiency House Plus in Berlin. Available online: https://www.buildup. $\mathrm{eu} / \mathrm{en} /$ practices/cases/efficiency-house-plus-berlin (accessed on 10 May 2020).

21. Dickert, J.; Hess, T.; Schegner, P.; Felsmann, C. Electrical design of an efficiency house plus. In Proceedings of the IEEE Pes Innovative Smart Grid Technologies Conference Europe, Berlin, Germany, 14-17 October 2012; pp. 1-7.

22. Fitton, R.; Swan, W.; Hughes, T.; Benjaber, M.; Todd, S. Assessing the performance of domestic heating controls in a whole house test facility. Build. Serv. Eng. Res. Technol. 2016, 37, 539-554. [CrossRef]

23. Fitton, R.; Swan, W.; Hughes, T.; Benjaber, M. The thermal performance of window coverings in a whole house test facility with single-glazed sash windows. Energy Effic. 2017, 10, 1419-1431. [CrossRef]

24. Ji, Y.; Lee, A.; Swan, W. Retrofit modelling of existing dwellings in the uk: The salford energy house case study. Int. J. Build. Pathol. Adapt. 2019, 37, 344-360. [CrossRef]

25. Ji, Y.; Fitton, R.; Swan, W.; Webster, P. Assessing overheating of the uk existing dwellings-A case study of replica victorian end terrace house. Build. Environ. 2014, 77, 1-11. [CrossRef]

26. De Angelis, E.; Ciribini, A.L.C.; Tagliabue, L.C.; Paneroni, M. The brescia smart campus demonstrator. Renovation toward a zero energy classroom building. Procedia Eng. 2015, 118, 735-743. [CrossRef]

27. Microrete Autosufficiente di Moduli Edilizi Alimentata da Energia Solare-Pvzen. Available online: http://www.denerg.polito. it/la_ricerca/ricerca_co_finanziata_dal_dipartimento/pvzen (accessed on 24 June 2020).

28. Openstudio. Available online: https://www.openstudio.net/ (accessed on 3 January 2021).

29. Sketchup. Available online: https://www.sketchup.com/ (accessed on 3 January 2021).

30. Energyplus. Available online: https:/ / energyplus.net/ (accessed on 3 January 2021).

31. Ashrae. International Weather for Energy Calculations (Iwec Weather Files) User Manual And Cd-Rom; Ashrae: Atlanta, GA, USA, 2001.

32. Uni 10339:1995-Impianti Aeraulici Al Fini Di Benessere. Generalità, Classificazione E Requisiti. Regole Per La Richiesta D'offerta, L'offerta, L'ordine E La Fornitura; Ente Nazionale Italiano di Unificazione (uni): Rome, Italy, 1995.

33. Decreto Del Presidente Della Repubblica Del 16 Aprile 2013, N. 74. Gazz. Uff. Della Repubb. Ital. 2013.

34. Decreto Ministeriale Del 26 Giugno 2015-Applicazione Delle Metodologie Di Calcolo Delle Prestazioni Energetiche E Definizione Delle Prescrizioni E Dei Requisiti Minimi Degli Edifici. Gazz. Uff. Della Repubb. Ital. 2015.

35. Matlab. Available online: https://uk.mathworks.com/products/matlab.html (accessed on 3 January 2021).

36. Spertino, F.; Ahmad, J.; Chicco, G.; Ciocia, A.; Di Leo, P. Matching between electric generation and load: Hybrid pv-wind system and tertiary-sector users. In Proceedings of the 2015 50th International Universities Power Engineering Conference (Upec), Stroke-On-Trent, UK, 1-4 September 2015; pp. 1-6.

37. Nguyen-Duc, T.; Nguyen-Duc, H.; Le-Viet, T.; Takano, H. Single-diode models of pv modules: A comparison of conventional approaches and proposal of a novel model. Energies 2020, 13, 1296. [CrossRef]

38. Ahmad, J.; Spertino, F.; Ciocia, A.; Di Leo, P. A maximum power point tracker for module integrated pv systems under rapidly changing irradiance conditions. In Proceedings of the 2015 International Conference On Smart Grid And Clean Energy Technologies, Icsgce 2015, Offenburg, Germany, 20-23 October 2015; pp. 7-11.

39. Spertino, F.; Graditi, G. Power Conditioning Units In Grid-Connected Photovoltaic Systems: A Comparison With Different Technologies and wide range of power ratings. Sol. Energy 2014, 108, 219-229. [CrossRef]

40. Spertino, F.; Fichera, S.; Ciocia, A.; Malgaroli, G.; Di Leo, P.; Ratclif, A. Toward the complete self-sufficiency of an nzebs microgrid by photovoltaic generators and heat pumps: Methods and Applications. IEEE Trans. Ind. Appl. 2019, 55, 7028-7040. [CrossRef]

41. Zou, Z.; Xu, J.; Mi, C.; Cao, B.; Chen, Z. Evaluation of model based state of charge estimation methods for lithium-ion batteries. Energies 2014, 7, 5065-5082. [CrossRef] 
42. Zhou, Y.; Li, X. Overview Of Lithium-Ion Battery Soc Estimation. In Proceedings of the 2015 IEEE International Conference on Information and Automation, Icia 2015-In Conjunction with 2015 IEEE International Conference on Automation and Logistics, Lijiang, China, 8-10 August 2015; pp. 2454-2459.

43. Meng, J.; Ricco, M.; Luo, G.; Swierczynski, M.; Stroe, D.I.; Stroe, A.I.; Teodorescu, R. An Overview and Comparison of Online Implementable Soc Estimation Methods For Lithium-Ion Battery. IEEE Trans. Ind. Appl. 2018, 54, 1583-1591. [CrossRef]

44. CEN-European Committee For Standardization. En 15378-3:2017-Energy Performance of Buildings-Heating and Dhw Systems in Buildings_Part 3: Measured Energy Performance, Module M3-10, M8-10; CEN: Brussels, Belgium, 2018.

45. Kichou, S.; Skandalos, N.; Wolf, P. Evaluation of photovoltaic and battery storage effects on the load matching indicators based on real monitored data. Energies 2020, 13, 2727. [CrossRef]

46. Zebra 2020: Nearly Zero-Energy Building Strategy 2020, Deliverable D2.1: Definition of Nearly Zero- Energy Buildings as Used for Market Tracking. Available online: https: / / zebra2020.eu/ (accessed on 3 January 2021). 